I N T ER N ATIONAL MONETARY FUND

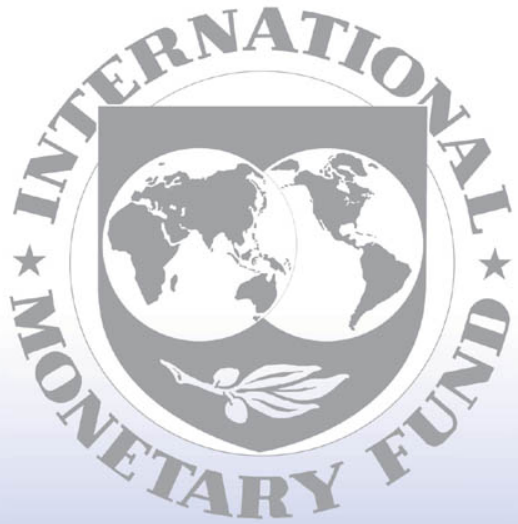

Staff

Country

Reports 


\title{
Japan: 2006 Article IV Consultation-Staff Report; Staff Supplement; and Public Information Notice on the Executive Board Discussion
}

Under Article IV of the IMF's Articles of Agreement, the IMF holds bilateral discussions with members, usually every year. In the context of the 2006 Article IV consultation with Japan, the following documents have been released and are included in this package:

- the staff report for the 2006 Article IV consultation, prepared by a staff team of the IMF, following discussions that ended on May 24, 2006, with the officials of Japan on economic developments and policies. Based on information available at the time of these discussions, the staff report was completed on June 30,2006. The views expressed in the staff report are those of the staff team and do not necessarily reflect the views of the Executive Board of the IMF.

- $\quad$ a staff supplement of July 18, 2006 updating information on recent developments.

- $\quad$ a Public Information Notice (PIN) summarizing the views of the Executive Board as expressed during its July 21, 2006 discussion of the staff report that concluded the Article IV consultation.

The document listed below has been or will be separately released.

Selected Issues Paper

The policy of publication of staff reports and other documents allows for the deletion of market-sensitive information.

To assist the IMF in evaluating the publication policy, reader comments are invited and may be sent by e-mail to publicationpolicy@imf.org.

\author{
Copies of this report are available to the public from \\ International Monetary Fund $\bullet$ Publication Services \\ $70019^{\text {th }}$ Street, N.W. • Washington, D.C. 20431 \\ Telephone: (202) 623-7430 • Telefax: (202) 623-7201 \\ E-mail: publications@imf.org • Internet: http://www.imf.org
}

Price: $\$ 15.00$ a copy

\section{International Monetary Fund Washington, D.C.}


This page intentionally left blank

CInternational Monetary Fund. Not for Redistribution 
INTERNATIONAL MONETARY FUND

JAPAN

\section{Staff Report for the 2006 Article IV Consultation}

Prepared by the Staff Representatives for the 2006 Consultation with Japan

Approved by Daniel Citrin and Carlo Cottarelli

June 30, 2006

- This report is based on discussions held by the Japan team in Tokyo during May 15-24 as well as policy discussions held by Ms. Krueger on June 5-6. The team comprised Messrs. Citrin (Head), Zanello, Kramer, Faulkner-MacDonagh, Iizuka, N'Diaye, and Ms. Edison (all APD), and Mr. Nakagawa (ICM). Mr. Khatri (OAP) also participated; Messrs. Kashiwagi and Kitahara (OED) took part in discussions. A companion Selected Issues paper provides supporting analysis.

- Counterparts: Discussions were held with Bank of Japan (BoJ) Governor Fukui; Minister of Finance Tanigaki, Minister of State for Economic and Fiscal Policy and Financial Services Yosano, Minister of Internal Affairs and Communications and Minister of State for Privatization of the Postal Services Takenaka, Vice Minister of Finance for International Affairs Watanabe, BoJ Deputy Governor Iwata, Member of the BoJ Policy Board Suda, and other senior officials, academics, and private sector representatives.

- Context of past surveillance: In recent years, the Fund and the authorities have generally agreed on the broad policy priorities - tackling deflation through monetary accommodation and moving to an appropriate post-deflation monetary framework, undertaking medium-term fiscal consolidation, revitalizing the corporate and financial sectors, and pursuing productivity-boosting reforms. However, the authorities have generally favored more moderate steps in some areas than the Fund, partly out of concern for the risks that stronger actions might pose.

- Japan's exchange rate is market determined. Japan has accepted the obligations of Article VIII. The exchange system is free of restrictions on the making of current international transactions, with the exceptions of those notified to the Fund in accordance with Executive Board Decision 144-(52/51) (Annex IV). 
Executive Summary

I. Introduction

II. Economic and Financial Backdrop ..................................................................

III. Three Macroeconomic Policy Challenges ................................................................. 7

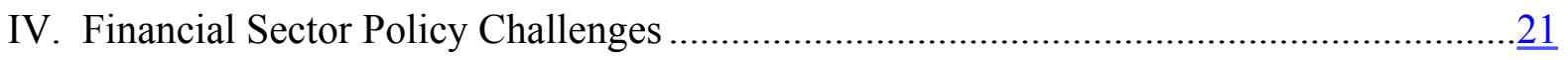

V. International Implications of Japan's Recovery and Policies ......................................

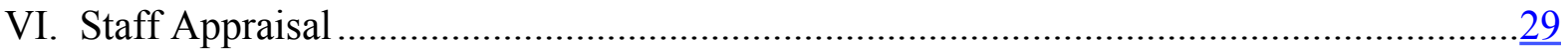

Boxes

1. The New Monetary Framework for the Bank of Japan .............................................

2. Fiscal Adjustment: Lessons from Selected OECD Countries .....................................14

3. Strategies for Fiscal Consolidation in Japan Economic and Financial Backdrop ...........15

4. Social Security Expenditure in Japan ...................................................................17

5. Reform of Government Financial Institutions ......................................................23

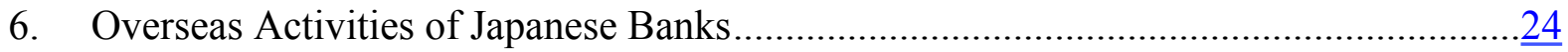

Figures

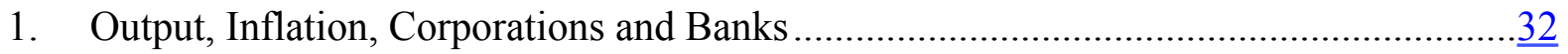

2. External Sector, Monetary and Fiscal Policy............................................................33

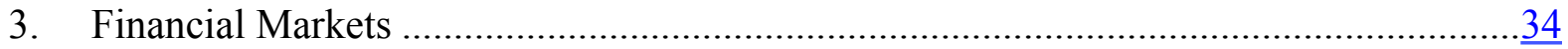

Tables

1. Selected Economic Indicators, 2002-2007 .............................................................. $\underline{35}$

2. General Government Operations, 2000-2006 .....................................................

3. External and Financial Indicators, 1998-2006 ........................................................

Annexes

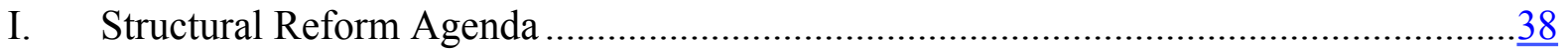

II. Debt Sustainability Analysis ….................................................................. 45

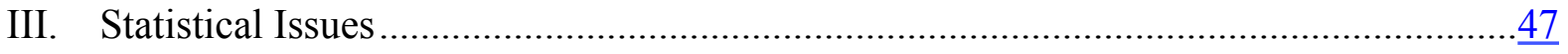

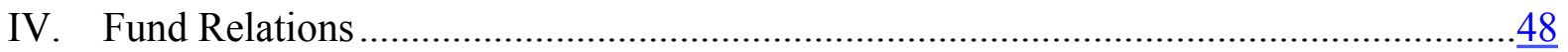




\section{EXECUTIVE SUMMARY}

- The post-bubble adjustment is essentially complete. Economic activity is expanding robustly, driven by domestic demand. There are downside risks stemming from external factors, but there are also upside risks to private consumption and investment.

- The financial and corporate sectors are strengthening further. Nonperforming loans continue to fall and bank lending is reviving, but core profits remain low; policy is focused on continuing revitalization while promoting growth of securities markets. Corporate restructuring is spurring productivity gains and yielding record profits.

- Monetary policy is normalizing. With core CPI positive $y / y$ for a few months and expected to remain so, in March the Bank of Japan shifted from targeting reserves to targeting the overnight policy interest rate (which remains at zero). It also introduced a new framework for its post-deflation policy approach.

- Fiscal consolidation is proceeding apace, but imbalances remain large. The authorities now project achieving a primary balance excluding social security in 2011 . The corresponding (estimated) deficit fell 1 percent of GDP in FY2005. However, the net debt ratio is high by advanced-country standards, and rising.

- The external surplus is narrowing. The trade balance fell in 2005, notwithstanding a yen depreciation. Recently, the yen has strengthened, but in effective terms remains relatively weak compared with the past. The risks posed by a disruptive adjustment of external imbalances remain a concern, particularly for the medium term.

- Reforms underway will strengthen the supply side. Steps include deregulation as well as product and labor market liberalization, with an aim to lift productivity and improve mediumterm growth prospects.

\section{Key Issues and Policy Discussions}

- The end of deflation and the smooth transition out of quantitative easing are milestones for monetary policy. In the near term, policy should remain accommodative, allowing inflation expectations to drift up. The new policy framework improves transparency, and continued effective communication about how it will be implemented will ensure that markets clearly understand the BoJ's intentions.

- The commitment to fiscal consolidation is welcome. With the expansion strong and the task large, a more front-loaded and ambitious adjustment would stabilize the debt in the medium term and buy insurance against fiscal or economic shocks. Also, by bolstering policy credibility, it would limit the risk of an undue rise in real interest rates.

- Accelerated structural reforms would pay additional dividends to Japan and the world. Stronger underlying growth would facilitate fiscal consolidation and support living standards in the face of population aging. It would also bolster world growth and support a more balanced pattern of global demand, which along with actions in other countries could promote a smooth adjustment of global imbalances. 


\section{INTRODUCTION}

1. Japan's post-bubble adjustment is essentially complete. Corporate and bank balance sheets are strong; employment and wages are rising; and-emblematically — the seven-year decline in core CPI has ended. The expansion is halfway into its fourth year and is close to becoming the longest on record.

2. Nonetheless, major policy challenges remain. The 2006 Article IV discussions focused on: the post-deflation monetary framework; the strategy to tackle large fiscal imbalances as demographic pressures mount; and the reform agenda to boost productivity and long-term growth. The discussions also examined the international dimensions of economic developments in Japan and policies that could best contribute to reducing the risk of a disorderly adjustment of global imbalances. The key challenges are similar to those flagged in the 2005 consultation, but the further waning of deflation pressures and continued improvement in the economic outlook, as well as the increased focus on global imbalances, strengthen the case for bold action.

3. Japan has entered a busy electoral year. Prime Minister Koizumi's tenure as the leader of the ruling party expires in September. The party will then elect a new leader/Prime Minister. A new cabinet will be nominated soon after. Elections for the Upper House of the Parliament are set to occur by July 2007.

\section{ECONOMIC AND FINANCIAL BACKDROP}

\section{Background}

\section{Japan's expansion has been strong.}

- Recent growth has been driven by domestic demand: 2005 GDP growth was over $2 \frac{1}{2}$ percent, with most impetus from private consumption and business investment. GDP grew at a (seasonally adjusted) annual rate of about 3 percent in the first quarter of 2006 (Figure 1).

- Deflation has ended: Core inflation (CPI excluding fresh food) has been positive since November 2005 (year-on-year core inflation was $1 / 2$ percent in April). The GDP deflator continues to decline, mainly reflecting a rise in import prices, but the implicit deflator for domestic demand is rising marginally. Land prices in major cities are rebounding after a fifteen-year slide.

- Labor markets are tightening: Labor shortages are emerging and the unemployment rate remains around an eight-year low, at 4.1 percent. Wages and bonuses have risen, although unit labor costs are still falling. Employment has picked up as well, notwithstanding a dwindling working age population. 
- The financial and corporate sectors are in their best shape in over a decade: Under tougher regulation, major banks' nonperforming loan (NPL) ratios fell to below 2 percent in March 2006. Progress at regional banks has been more modest; NPLs nevertheless have fallen to $4 \frac{1}{2}$ percent of total loans. Intense corporate restructuring has helped to reduce debt-to-sales ratios across a broad range of sectors. Indeed, for all firms taken together, the ratio is at the lowest level since the bubble, and for manufacturers, at the lowest level in 25 years. Corporate restructuring has also buoyed profits to record highs and unlocked productivity gains. With credit supply constraints eased and loan demand revived, bank lending (adjusted for provisions and write-offs) has been trending up since around mid-2005, after about eight years of contraction.

- The external surplus is narrowing: The trade balance fell in 2005 by $3 / 4$ percent of GDP, in spite of a real effective yen depreciation. The current account declined more modestly as factor income surged (Figure 2). Heavy purchases of foreign bonds and repatriation of funds by nonresidents led to large net capital outflows, notwithstanding record foreign purchases of domestic equities.

- The yen has started to strengthen: After depreciating against the U.S. dollar by nearly 15 percent during 2005 as interest rate differentials widened, the yen has appreciated modestly this year, as markets focused on global imbalances and reassessed the likely pace of monetary tightening in major economies. In this context, some market participants have unwound "yen carry trades" that took place during the quantitative easing period. ${ }^{1}$ Despite the recent strengthening, in nominal and real effective terms the yen remains about $6 \frac{1}{4}$ percent weaker than a year ago; the real effective yen is now about as weak as at the time of the 1985 Plaza Accord. No foreign exchange market intervention has occurred since March 2004.

\section{Outlook and Risks}

\section{The near-term outlook is favorable and risks are balanced.}

- Baseline: GDP growth is projected at nearly 3 percent in 2006 (when the output gap is expected to turn positive for the first time since 1992) and just above 2 percent in 2007. With offsetting trends in the trade balance and factor income, the current account surplus would hover around $3 \frac{1}{2}$ percent of GDP.

- Risks: Downside risks are mostly external—volatile oil prices, rising long-term interest rates, or a global slowdown. Low inflation raises the possibility of renewed deflation,

\footnotetext{
${ }^{1}$ For example, during most of the quantitative easing period, Japanese banks acquired about \$4-5 billion in short-term foreign assets each month.
} 
particularly if a disorderly unwinding of global imbalances occurs, but private consumption and investment are subject to upside risks.

\section{Over the medium term, GDP growth is projected to revert to potential and the}

current account to narrow. Staff has raised its estimate of potential growth to

$13 / 4-2$ percent, largely because of a rising capital contribution, but it could be higher with stepped-up reforms, increased labor-force participation, and a recovery in R\&D. ${ }^{2}$ Faster productivity growth in a broad range of sectors would also decrease the current account surplus over time (by reducing private saving and boosting investment as permanent income rises), countering the effects of fiscal consolidation. ${ }^{3}$

\begin{tabular}{|c|c|c|c|c|c|c|c|}
\hline \multicolumn{8}{|c|}{$\begin{array}{c}\text { Japan: Medium-Term Projections, 2005-11 } \\
\text { (Percentage change from the previous period, unless otherwise indicated) }\end{array}$} \\
\hline & 2005 & 2006 & 2007 & 2008 & 2009 & 2010 & 2011 \\
\hline Real GDP 1/ & 2.6 & 2.9 & 2.1 & 1.9 & 1.9 & 1.8 & 1.7 \\
\hline Total domestic demand & 2.5 & 2.6 & 2.2 & 2.0 & 1.9 & 1.8 & 1.7 \\
\hline Net exports (contribution) & 0.2 & 0.4 & 0.0 & 0.0 & 0.0 & 0.0 & 0.0 \\
\hline Unemployment rate (percent) & 4.4 & 4.1 & 4.0 & 4.0 & 4.0 & 4.0 & 4.0 \\
\hline CPI inflation & -0.3 & 0.6 & 0.6 & 1.3 & 1.5 & 1.9 & 2.0 \\
\hline \multicolumn{8}{|l|}{ Savings-investment balances 2 / } \\
\hline Private & 6.1 & 6.0 & 5.5 & 5.2 & 4.8 & 4.4 & 4.3 \\
\hline Public & -2.5 & -2.2 & -2.0 & -1.8 & -1.5 & -1.3 & -1.2 \\
\hline Current Account Balance 2/ & 3.6 & 3.7 & 3.5 & 3.4 & 3.3 & 3.1 & 3.0 \\
\hline Trade Balance 2/ & 2.1 & 1.8 & 1.6 & 1.6 & 1.5 & 1.4 & 1.2 \\
\hline Exports & 12.4 & 13.1 & 13.3 & 13.8 & 14.1 & 14.5 & 14.9 \\
\hline Imports & 10.4 & 11.4 & 11.7 & 12.2 & 12.7 & 13.2 & 13.7 \\
\hline Non-factor Services Balance 2/ & -0.5 & -0.4 & -0.5 & -0.5 & -0.6 & -0.7 & -0.8 \\
\hline Income and Transfers Balance 2/ & 2.1 & 2.3 & 2.3 & 2.3 & 2.4 & 2.5 & 2.5 \\
\hline \multicolumn{8}{|c|}{ Sources: Global Insight, Nomura database; and Fund staff estimates. } \\
\hline \multicolumn{8}{|c|}{$\begin{array}{l}\text { 1/ Annual growth rates and contributions are calculated from seasonally adjusted data. } \\
2 \text { / In percent of GDP. }\end{array}$} \\
\hline
\end{tabular}

\section{The Authorities' Views}

\section{The authorities broadly agreed with this outlook.}

- On risks, they noted that the possibility of a deflationary spiral is remote, given the stronger financial and corporate balance sheets and the closing output gap.

\footnotetext{
${ }^{2}$ Returns to R\&D have probably been depressed by Japan's decade-long stagnation. The Selected Issues paper presents an econometric analysis of the factors driving potential GDP and the possible gains from reforms.

${ }^{3}$ Country Report No. 05/272 analyzes the potential contribution of faster productivity growth in Japan to an orderly resolution of global imbalances.
} 
- On price developments, the authorities welcomed the waning of deflationary pressures, but some officials remain concerned that selected price indicators are still declining slightly.

- On potential growth (currently estimated at $1 \frac{1}{2}-2$ percent by the BoJ and Cabinet Office), the authorities considered that more competition, efficiency gains in public services, and further IT diffusion and R\&D could boost longer-term real growth to about $2 \frac{1}{4}$ percent, in spite of population aging.

\section{Three Macroeconomic Policy Challenges}

The mission and the authorities agreed that an appropriate post-deflation monetary framework, a well-designed fiscal consolidation, and productivity-boosting reforms are complementary elements of a strategy for sustained non-inflationary growth. There was also agreement that these policies would contribute to global financial stability, as part of concerted efforts to promote an orderly resolution of global imbalances. The discussions focused mainly on areas where the mission considered that policy implementation might be accelerated or strengthened.

\section{A. Toward a Post-Deflation Monetary Framework}

\section{Background}

\section{The BoJ has shifted its strategy from targeting banks' excess reserves (quantitative easing) to targeting the overnight interest rate.}

- The pre-announced conditions for ending quantitative easing (in place since 2001) were met in early 2006, and the BoJ announced an exit on March 9, indicating that it would gradually drain liquidity while keeping overnight interest rates effectively at zero.

- Since March, excess reserves have declined from over $¥ 30$ trillion to around $¥ 10$ trillion, with short rates stable. The money market, which withered under quantitative easing, is coming back to life, as institutions rely less on the BoJ for funding and the opportunity cost of idle balances rises.

\section{The new monetary framework introduces some novel features (Box 1):}

- An anchor for inflation expectations. The guidepost is the BoJ's Policy Board's "understanding of price stability" as annual CPI inflation of zero to two percent. This range captures the current views of Board members about the level of inflation consistent with price stability over the "medium and longer term." It is not a target to achieve over a preset horizon, and it will be reviewed annually, as the Board's views on the economy evolve. 


\section{Box 1. The New Monetary Policy Framework for the Bank of Japan}

On March 9, 2006, the BoJ ended quantitative easing (QE) and now operates under a framework that strikes a balance between policy pre-commitment (adopted under $\mathrm{QE}$ ) and flexibility by:

- Disclosing an understanding based on views of Policy Board members of price stability in current circumstances as headline CPI inflation of 0-2 percent over the medium to long term;

- Deciding the conduct of monetary policy by analyzing the risks to price stability from two perspectives: (i) near-term (1-2 year) forecast of economic activity and prices; and (ii) longer-term threats including those arising from low probability—but high cost—risks.

- Outlining the BoJ's analysis from the two perspectives and disclosing it periodically (as a rule, it would appear in the Bank's semi-annual report). This analysis would expand the current practice of disclosing (in the semi-annual report) the Policy Board members' forecasts of activity and prices.

The new framework offers a more detailed evaluation of risks, providing further elaboration on the BoJ's forecasts. In this manner, markets benefit from a structured discussion of the Bank's views on conjunctural conditions and the policy outlook. At the same time, the BoJ still retains the flexibility to respond to economic developments not directly reflected in CPI data.

The BoJ describes price stability using the headline CPI, because of its advantages over other indices. The CPI is well-understood, timely, and covers items used by the public in forming price expectations. Other indices are either specific to a sector (such as wholesale or service price indices) or not timely (such as the GDP deflator, which is also subject to substantial revisions). Core inflation is not used because price stability is a medium to long-term concept, when core and headline inflation should agree.

The inflation range in the understanding may appear low, but the BoJ has considered various biases and frictions in the Japanese context. ${ }^{1}$ Conceptually, price stability occurs at zero inflation, although statistical biases mean that in practice inflation must be positive. Central banks have also noted that deflation can be costly and have built in a small safety margin. Against this backdrop, the BoJ has explained that the current range reflects that:

- The statistical bias of the CPI index is low, thanks to recent methodological improvements.

- Japanese wages exhibit more downward flexibility than in other countries, because bi-annual bonus payments represent around 20 percent of compensation and are routinely adjusted by firms with due regard to business conditions.

More generally, the BoJ has assessed the need for a safety margin against five factors: (i) degree of rigidity in nominal wages; (ii) level of potential growth; (iii) robustness of the financial system; (iv) availability of fiscal policy; and (v) effectiveness of monetary policy transmission mechanism.

More fundamentally, the BoJ is not adopting an inflation target of 0 to 2 percent, but rather is analyzing developments from two perspectives to ensure that the economy is on a sustainable path with price stability. This means that, in deciding monetary policy, they would examine current, nearterm forecasts (1-2 years forward) and adjust monetary policy accordingly. At the same time, the BoJ has learned the lesson of the bubble years: the economy can overheat - and overinvestment can build rapidly — while inflation remains low. Hence, the BoJ wants to preserve the flexibility to act, regardless of the central forecast for inflation.

${ }^{1}$ See "The Bank's Thinking on Price Stability," March 10, 2006, available as a background note to the March 9 announcement. 
- An emphasis on the forward-looking orientation of policy. Monetary settings will reflect an assessment of economic conditions from two perspectives focused on: (i) the outlook for growth and prices one to two years ahead; and (ii) the risks of imbalances- such as asset bubbles or overinvestment - that could undermine price and output prospects over a longer horizon.

- Broad parameters for communicating policy. Monetary policy decisions will be explained in terms of the two perspectives. The underlying analysis will be discussed from time to time and, as a rule, in the BoJ's semi-annual Outlook for Economic Activity and Prices.

\section{Policy Issues and Staff's Views}

10. The exit from quantitative easing has been orderly and monetary operations have finally normalized. The limited volatility in money markets suggests skillful liquidity management and effective communication. Both have worked to ease concerns in some quarters about a premature tightening.

\section{The new framework is broadly in line with past staff advice and improves} transparency in the post-deflation environment. Quantitative easing provided an unusually high degree of policy certainty through a commitment to maintain excess liquidity until core CPI showed durable increases. The new framework is appropriately more flexible, given that inflation risks have become two-sided, but also necessarily more complex.

\section{The authorities should continue to communicate how the new policy framework} will be implemented to ensure markets clearly understand the BoJ's policy intentions.

- Understanding of price stability: The range reflects differences of view among Policy Board members about the extent to which structural changes, statistical bias, and conjunctural developments are influencing the CPI, as well as Japan's historically low inflation. Nevertheless, from a medium-term perspective, a lower bound of zero seems too low to prevent unforeseen events from pushing the economy back into deflation. Accordingly, it would be desirable for the range (or its floor) to rise over time, as inflation becomes better entrenched. Meanwhile, more explicit communication on the risks associated with inflation at the lower end of the range would guide market expectations and provide insights on the policy strategy.

- Policy stance: With little danger of an inflation surge at present, policy should remain accommodative, allowing inflation expectations to drift up. Taylor-like rules suggest that a near-zero rate is appropriate for the time being. When tightening begins, it should proceed gradually. That said, policy should also take account of longer-term risks to sustained noninflationary growth, such as those associated with emergent asset price bubbles or other imbalances, especially against the backdrop of a combination of robust 
growth and limited inflation pressures. ${ }^{4}$ Such imbalances do not seem to exist at present, but it would be appropriate, as per the authorities' intention, to be attuned to incoming data and respond flexibly.

13. With no room for fiscal maneuver, monetary policy would need to take the lead in offsetting adverse shocks. If abrupt movements in foreign exchange markets or other shocks were to threaten price stability, the BoJ could communicate clearly that such developments would be taken into account - together with other data - in setting monetary policy.

\section{The Authorities' Views and Policy Intentions}

\section{BoJ officials welcomed the normalization of monetary operations.}

- End to pre-commitment: They noted that ending the explicit pre-commitment of quantitative easing has increased flexibility, but also raised policy uncertainty for market participants.

- Reinvigoration of the money markets: The shift is encouraging a better allocation of funds and improvements in risk management, as financial institutions reestablish credit lines and reassess counterparty risks.

\section{BoJ officials see the new framework as different from that of other central}

banks. On its specific elements:

- Understanding of price stability: The authorities stress that the range is not an inflation target, nor a commitment to achieve a certain inflation rate over any timeframe. Instead, it is a guide to the public that Board members consider 0-2 percent CPI inflation as consistent with price stability at present. While this range can adjust over time, as views on inflation evolve along with the economy and the composition of the Policy Board, toofrequent changes should be avoided, since they could destabilize inflation expectations.

- Lower bound of the "understanding" range: Officials point out that inflation has historically been at least 1 percent lower in Japan than in other advanced economieseven abstracting from the deflation period. This has colored the public's perception of price stability (as reported in surveys). However, in accordance with the role of the "understanding" as a summary of prevailing views at the Board and not as a target, the $\mathrm{BoJ}$ is not aiming to achieve zero percent inflation.

\footnotetext{
${ }^{4}$ World Economic Outlook, April 2006, Chapter III suggests that globalization has restrained inflation pressures.
} 
- Policy stance: The authorities agreed that monetary policy should remain accommodative for now, but also aim to engineer a soft landing for the economy. While the BoJ is in no hurry to remove accommodation, markets have priced in gradual future rate increases, which are consistent with the BoJ's outlook for a soft landing.

- Going forward, monetary settings will be data-dependent. The BoJ will examine incoming data closely to see if a soft landing is likely. Officials recognize that the situation can change rapidly, especially as the strengthening monetary transmission mechanism amplifies the effects of existing accommodation.

- In the unlikely event that deflation reappears, the BoJ will respond appropriately. One option could be announcing a policy pre-commitment, if necessary.

- Evaluation of longer-term risks: Bank officials view the "second perspective" as unique and important. Monetary policy must respond to low probability—but high cost—risks, such as large investment swings. For example, communication about longer-term imbalances might have prevented the events at the root of the late 1980s bubble. They agreed that further elaboration of the "second perspective" will be helpful.

- Implementation of the framework: The authorities noted that markets will need to learn to adjust to greater policy uncertainty. This is unavoidable, given the end of deflation and the concomitant change in monetary policy objectives. While the new framework involves some ambiguity (for the sake of flexibility), the BoJ will continue to explain clearly its decisions and views, in the context of the "two perspectives."

\section{B. Tackling Fiscal Imbalances}

\section{Background}

\section{Fiscal imbalances remain worrisome, but consolidation is proceeding apace.}

- Imbalances are large: Deficits for 13 consecutive years have propelled gross and net general government debt to about 180 percent and 85 percent of GDP, and both continue to rise. Population aging will heighten already strong spending pressures (Annex II presents a debt sustainability analysis).

- A consolidation plan is in place: The plan revolves around a reference path for the primary account of the general government excluding social security, which aims first at achieving balance and later at reducing the debt ratio. Balance is to be achieved through an average yearly adjustment of $1 / 2$ percent of GDP. However, the underlying measures have not been spelled out yet, and a balance would not be sufficient to stabilize the debt ratio. The plan has undergone revisions over time: in January 2006, the indicative target date for a balance was brought forward to FY2011, reflecting better-than-anticipated 
budgetary outcomes (thanks to cyclical buoyancy and one-off factors). More recent updates have reflected a debate on the appropriate interest rate/growth rate differential assumed in the debt projections. A prudent approach that envisages a positive differential over the medium term seems to have carried the day but future elaboration of the reference path for consolidation will likely provide alternative scenarios.

- Consolidation is ahead of the authorities' schedule: For the reasons mentioned above, the outturn for FY2005 (ended in March) was likely better than projected a year ago, with a decline in the primary deficit excluding social security of perhaps 1 percent of GDP. The FY2006 budget, which rolls back past income tax cuts, envisages a fall of some $3 / 4$ percent of GDP in the general expenditure of the general account of the central government, compared to the FY2005 initial budget. ${ }^{5}$ The general government

\begin{tabular}{|c|c|c|c|c|}
\hline \multicolumn{5}{|c|}{ Central Government: General Account } \\
\hline & \multirow{2}{*}{$\begin{array}{c}\text { FY2004 } \\
\text { Revised 1/ }\end{array}$} & \multicolumn{2}{|c|}{ FY2005 } & \multirow{2}{*}{$\begin{array}{l}\text { FY2006 } \\
\text { Initial 2/ }\end{array}$} \\
\hline & & Initial & Revised 1/ & \\
\hline & \multicolumn{4}{|c|}{ (In percent of GDP) } \\
\hline \multicolumn{5}{|l|}{ Central Government/General Account } \\
\hline Revenue & 10.1 & 9.5 & 10.5 & 9.5 \\
\hline General expenditure & 10.5 & 9.7 & 10.1 & 9.0 \\
\hline Other expenditures 3 / & 7.0 & 6.5 & 7.0 & 6.2 \\
\hline Bond issuance & 7.4 & 6.8 & 6.6 & 5.7 \\
\hline \multicolumn{5}{|l|}{ General Government (Fund staff estimates) } \\
\hline Balance & -5.6 & & -5.3 & -5.0 \\
\hline Primary balance excluding social security & -3.9 & & -3.0 & -2.3 \\
\hline \multicolumn{5}{|c|}{$\begin{array}{l}\text { Sources: Ministry of Finance and Fund staff estimates. } \\
\text { 1/ Post-supplementary budget/estimated outturn. } \\
\text { 2/ Approved budget for central government general account. } \\
\text { 3/ Debt service and transfers to local governments. }\end{array}$} \\
\hline
\end{tabular}
primary balance (excluding social security) would fall by a similar amount.

- The authorities are now fleshing out tax and expenditure reforms for the medium term. Detailed options will be announced in the June-July releases of a "Roadmap for IncomeExpenditure Reform" and the Basic Policies for FY2006 - the annual broad guidelines for fiscal policy and reform initiatives. A variety of reforms is under consideration and some, described below, are already underway.

Japan: Baseline Fiscal Outlook (In percent of GDP, fiscal year basis)

\begin{tabular}{|c|c|c|c|c|c|c|c|c|}
\hline & \multirow[b]{2}{*}{2004} & \multirow{2}{*}{$\begin{array}{r}\text { Est. } \\
2005\end{array}$} & \multicolumn{6}{|l|}{ Proj. } \\
\hline & & & 2006 & 2007 & 2008 & 2009 & 2010 & 2011 \\
\hline \multicolumn{9}{|l|}{ General government } \\
\hline Revenue & 28.7 & 29.1 & 29.7 & 30.4 & 31.0 & 31.7 & 32.3 & 32.9 \\
\hline Expenditure & 34.3 & 34.5 & 34.6 & 35.2 & 35.6 & 36.0 & 36.4 & 37.0 \\
\hline Balance & -5.6 & -5.3 & -5.0 & -4.8 & -4.6 & -4.3 & -4.1 & -4.2 \\
\hline Primary Balance excluding social security & -3.9 & -3.0 & -2.3 & -1.8 & -1.2 & -0.6 & -0.2 & 0.0 \\
\hline
\end{tabular}

\footnotetext{
${ }^{5}$ The general account of the central government provides the main framework for the budget. Information on local governments is available with lags.
} 


\section{Policy Issues and Staff Views}

\section{The key fiscal challenge is to put public finances on a more sustainable footing.}

The main issues are: the desirable pace of consolidation, the appropriate mix of expenditure and revenue measures, and their timing.

- On the pace: The FY2006 budget is passed, but savings should be sought and an expansionary supplementary budget should be avoided. More broadly, there remains a case for a more ambitious medium-term adjustment than in the authorities' plan.

- An adjustment of $3 / 4$ percent per year on average over six years, or an additional $1 / 4$ percent per year compared with the authorities' projection, would buy "policy insurance" and boost the plan's credibility. Such an adjustmentcumulatively about $4 \frac{1}{2}$ percent of GDP - would achieve the primary surplus excluding social security needed to stabilize the debt ratio. Experience with large

\begin{tabular}{|lccc|}
\hline \multicolumn{3}{|c|}{ Primary Balance Needed to Stabilize Debt } \\
\hline & $\begin{array}{c}\text { General } \\
\text { Government } \\
\text { Government }\end{array}$ & $\begin{array}{c}\text { Social } \\
\text { Security }\end{array}$ & $\begin{array}{c}\text { excl. Social } \\
\text { Security }\end{array}$ \\
\hline FY2006 & -3.4 & -1.1 & -2.3 \\
FY2012 & 0.9 & -1.1 & 2.0 \\
Change & 4.3 & 0.0 & 4.3 \\
\hline Source: Staff estimate. & & & \\
\hline
\end{tabular}
consolidations in selected OECD countries suggests that consolidation at such a pace need not have a significant negative impact on output (Box 2).

- Barring a deterioration of the conjuncture, there is a strong case for front-loading the adjustment, with initial annual adjustments above $3 / 4$ percent of GDP. Above-potential growth and an accommodative monetary stance provide a good environment in which to bring forward deficit reduction, and thereby contain risk premia and prepare for the fiscal impact of population aging. ${ }^{6}$

- On composition and timing: Model-based simulations of alternative adjustment strategies suggest that a package of expenditure and tax measures will be needed to regain sustainable debt dynamics (Box 3). ${ }^{7}$ In light of the prospective evolution of social security outlays, and the sizeable reduction in spending so far, expenditure cuts alone do not seem

\footnotetext{
${ }^{6}$ Given the relatively small fiscal multipliers and a weak relationship between output and prices, a more ambitious fiscal plan on the order of the staff's recommendation is unlikely to markedly dampen growth or rekindle deflation pressures.

${ }^{7}$ The Selected Issues paper analyzes consolidation strategies using the IMF's Global Fiscal Model.
} 


\section{Box 2. Fiscal Adjustment: Lessons from Selected OECD Countries}

A number of OECD countries have undergone large fiscal adjustments in recent decades. This box draws lessons from these experiences, focusing on Japan's previous consolidation of 1980-1988, Australia (1993-1999), Canada (1992-1999) and the United Kingdom (1993-1999).

Each of these countries experienced large improvements in their primary balances, ranging between 5.1 percent of GDP (Australia) and 9.7 percent of GDP (Canada). These consolidations took, on average, 7 years to be completed. Moreover, the average pace of consolidation was 1.1 percent of GDP, considerably higher than the pace of $1 / 2$ percent per year

\begin{tabular}{|lccc|}
\hline \multicolumn{4}{c|}{ Table. Fiscal consolidation episodes in selected OECD countries } \\
\hline Country & $\begin{array}{c}\text { Period of Fiscal } \\
\text { Consolidation }\end{array}$ & $\begin{array}{c}\text { Change in Primary } \\
\text { Balance }\end{array}$ & $\begin{array}{c}\text { Yearly Average } \\
\text { Adjustment }\end{array}$ \\
\hline Japan & $1980-88$ & 5.7 & 0.7 \\
Australia & $1993-99$ & 5.1 & 0.8 \\
Canada & $1992-99$ & 9.7 & 1.4 \\
United Kingdom & $1993-99$ & 9.3 & 1.6 \\
\hline
\end{tabular}
currently envisaged by the Japanese authorities. The pace of adjustment in Japan during the 1980 s was about $3 / 4$ percent of GDP per year, which is the same pace the staff is recommending for the current consolidation.

The composition of fiscal adjustment has varied across countries. Adjustments have tended to rely on spending cuts, with these cuts representing more than half of the total adjustment effort. In the case of Canada, almost the entire adjustment was a result of expenditure reductions, while in Australia the adjustment occurred almost entirely through revenue increases. Expenditure measures tended to be spread across multiple categories, with the United Kingdom and Canada making sizeable

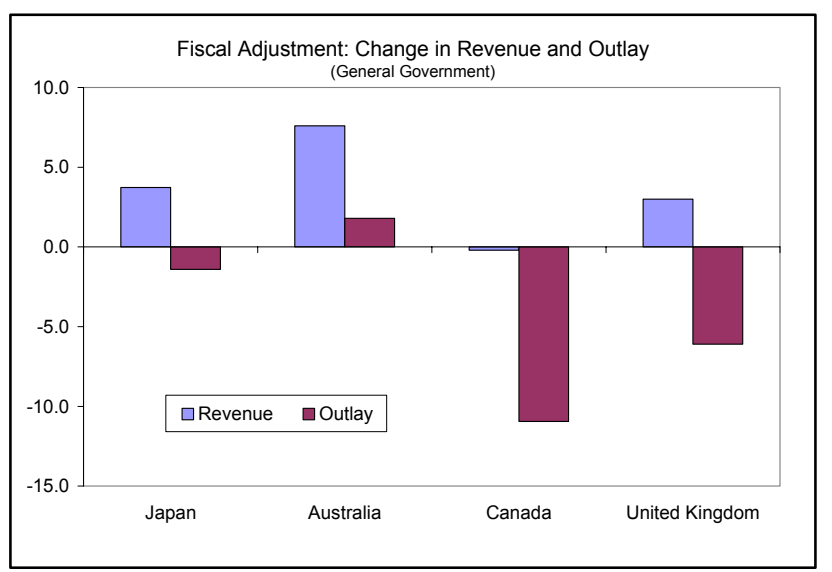
cuts to the government wage bill and transfers. Revenue increases tended to emphasize hikes in direct rather than indirect taxes.

Large adjustments have generally had a positive macroeconomic impact. Average growth rates, during consolidations varied across countries, but were at or near potential growth in each episode. Unemployment rates fell in three of the four cases, rising only slightly in Japan from an initial low level. The change in the current account balance was mixed, improving in Japan and Canada while declining in Australia and the United Kingdom.

In sum, the experience with fiscal consolidation has been encouraging. Successful fiscal adjustments have been diverse in their design and have not tended to be accompanied by economic downturns. 


\section{Box 3: Strategies for Fiscal Consolidation in Japan}

A key issue in the current fiscal debate is fiscal design - the expenditure-tax mix in fiscal adjustment. In order to contribute to this debate, staff have evaluated the macroeconomic effects of various strategies for fiscal consolidation, using the IMF's Global Fiscal Model (GFM). The GFM is a dynamic general equilibrium model that incorporates both the traditional demand side effects as well as the supply side and spillover effects, which permits an assessment of Japanese fiscal policy from a multilateral perspective. The simulations focus on two main issues: the composition of adjustment and its timing.

\section{Preliminary results show that:}

- Reducing social security transfers has a moderately smaller negative short-run impact compared with raising taxes or cutting other government expenditure (the figure shows expenditures other than transfers and interest payments). Among the revenue measures, a VAT increase has the least negative effect on output. Overall, the fiscal multipliers in the model appear consistent with those reported in the literature (around unity or less in the short run, and smaller in the long run).

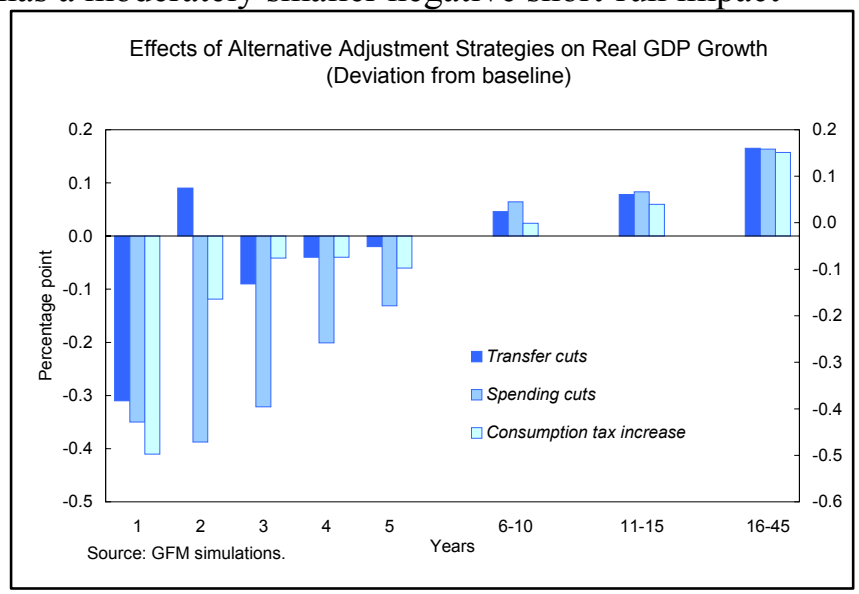

- Given the difficulty of relying only on expenditure cuts in light of the large needed medium-term fiscal adjustment in Japan, a package of measures involving lower government spending, lower government transfers, and a higher VAT rate was investigated. This package compares favorably to only increasing the VAT rate or only reducing government spending in terms of output effects.

- A modestly more ambitious consolidation than the authorities' plans (an additional $1 / 4$ percent of GDP per year as recommended by staff) would, if sustained, stabilize the debt to GDP ratio and increase long-term output by promoting capital accumulation.

As regards spillovers to global output from fiscal adjustment in Japan, the long-run effects are estimated to be modest but positive, reflecting higher output in Japan and lower world interest rates as a result of Japan's fiscal adjustment. This result is largely invariant to the fiscal design. 
a realistic strategy to balance the primary account, much less to achieve a surplus. ${ }^{8}$ The empirical analysis indicates that, on the revenue side, an increase in the consumption tax is preferable to other tax revenue-enhancing measures, with respect to the impact on output. An early adoption of the package also dominates a strategy of a more protracted fiscal adjustment.

- On specific measures: In the mission's view, options for medium-term consolidation would include: $:^{9}$ (i) reducing investment (despite drastic cuts, public investment remains, at $3 \frac{1}{2}$ percent of GDP, much higher that in other advanced economies); (ii) seeking economies through civil service reform (although the civil service in Japan is small by industrial countries' standards); (iii) broadening corporate and personal income tax bases (about 50 percent of personal income is taxable, compared to almost 80 percent in the United States and over 90 percent in the United Kingdom); (iv) raising the consumption tax (now very low by international standards); (iv) reforming the budget framework to consolidate the host of earmarked Special Accounts, which limit the scope for expenditure control; ${ }^{10}$ and (vi) further reforms of the social security system, to address growing demographic pressures (Box 4).

\section{The Authorities' Views and Policy Intentions}

18. The authorities give fiscal consolidation top priority. They noted the progress made in the last 2 fiscal years when the primary balance (excluding social security) declined by nearly $2 \frac{3}{4}$ percent of GDP. Their views on the issues raised by the mission are:

- On the pace: Fiscal consolidation should be paced flexibly, with due account of economic conditions. Numerical consolidation targets carry risks of excessive rigidity and policy pro-cyclicality, as was the case in the late 1990s when a rule-based approach was tried. Nonetheless, consolidation will proceed as fast as possible and overperformance relative to initial budget targets is likely.

\footnotetext{
${ }^{8}$ Achieving balance entails an adjustment equivalent to around one quarter of the general government's FY2005 primary spending (excluding social security benefits). Spending cuts have fallen particularly heavily on public investment, which has been reduced by over $2 \frac{1}{2}$ percent of GDP over the past 10 years.

${ }^{9}$ These include some measures where progress has already been made or is in train.

${ }^{10}$ Streamlining special accounts would also increase fiscal transparency. As a related issue, the compilation and dissemination of fiscal data (as highlighted in the 2005 data ROSC) remains inadequate, complicating policy evaluation and design.
} 


\section{Box 4. Social Security Expenditure in Japan}

Official estimates indicate that that government expenditure on social security would rise to about 22 percent of GDP by 2025, up from about 18 percent of GDP in 2006, under a noreform scenario. However, recent and planned reforms may keep this trend in check.

The 2004 public pension reform envisages an increase in contribution rate from 13.6 percent to 18.3 percent of salary by 2017 for the Employee Pension Insurance (EPI) scheme, which covers all private employees. The flat contribution to the universal National Pension scheme will also increase by 27 percent in real terms by 2017 . The EPI replacement ratio will gradually be reduced from 59 percent to 50 percent through "macro-indexation" (an index will be defined every year reflecting any decline in pension contributions and any increase in life expectancy; indexation of benefits would then be to CPI inflation minus this index). Finally, under the 2004 reform, the government contribution to the National Pension will increase from $1 / 3$ to $1 / 2$ of total benefits by 2009 .

Medical care reform was voted into law in June 2006. The key elements are:

- Cost containment. In the short run, measures will be introduced to trim medical expenditure by revising medical fees and drug tariffs downward by about 3 percent and by raising out-of-pocket payments for the well-to-do elderly to 30 percent (from 20 percent). In the medium term, measures will be introduced to increase the role of preventive medicine and reduce the length of hospital stays. Furthermore, five-year reviews of the expenditure trends will identify further possible areas for cost containment.

- Medical insurance scheme. A new system for the elderly will be introduced in FY2008, to which the elderly are expected to contribute directly.

- Reorganization of insurers. Small insurers are to be consolidated at the prefectural level, which should improve risk sharing.

These reforms are officially projected to produce savings of about $¥ 21$ trillion (about 3 percent of GDP) by 2025. The savings would be broad based, but pension reform would yield the largest economies. However, there are risks that the government's projections are overly optimistic. Specifically, it has been argued that the lower-than-expected birth rate may create a revenue shortfall for the pension system. In addition, measures (equivalent to about 1 percent of GDP) still need to be identified to

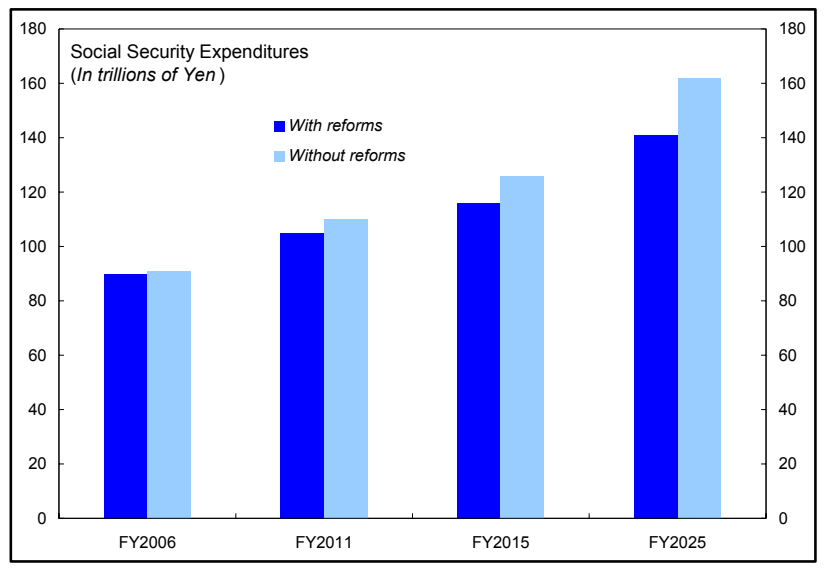
finance the increased share of the government's contribution to the national pension scheme. 
- On composition and timing: A mixture of expenditure and revenue measures will be considered, but spending cuts will probably account for at least half of the adjustment. This would be consistent with the objective of paring back the government's role in the economy - a plank of the administration's reform program. The government is expected also to introduce separate consolidation targets for the central and local governments in the forthcoming Basic Policies, as well as a second phase in the fiscal adjustment process - to steadily reduce the debt to GDP ratio over 2012-2015. ${ }^{11}$

- On specific measures: Current efforts have focused on spending control and administrative reform. Planned cuts will affect: personnel expenses, defense, agricultural subsidies, public investment, and social security transfers. Tax reform is also in the pipeline. As regarded issues raised by the mission:

- Civil service reform will reduce the number of government employees by more than 5 percent over the next five years and could halve the central government's wage bill (including Japan Post) as a share of GDP in ten years. Efficiency gains are expected to safeguard the quality of public services.

- Public investment of the general government is still large, although public works spending in the general account is back at its 1990 level. Overall, there is scope for further cuts in local jurisdictions.

- A comprehensive review of the tax system is in train. It will focus, inter alia, on the consumption tax, the income tax, the corporate tax, and the inheritance tax, with the aim of fairer and more efficient taxation. Conclusions about comprehensive tax changes (including an increase in the consumption tax) will be reached in FY2006. Other measures to boost non-tax revenues, such as sales of public assets, are being discussed.

- On social security reforms, legislation to rationalize the healthcare system has been enacted. The law increases co-payments by the affluent elderly and puts in place a framework for periodic expenditure reviews (with a view to identifying pressure points and remedial action).

- Special accounts would be rationalized under a proposed new law. ${ }^{12}$ The aim is to increase the transparency and accountability of the budgetary process as well as to identify potential savings.

\footnotetext{
${ }^{11}$ Inter-governmental relationships were redefined in the context of the 2003-2006 "trinity reform" which, for the most part, traded off subsidies from the center for taxing powers at the periphery. An unresolved issue concerns a possible reform of the Local Allocation Tax - a block grant of about 3 percent of GDP.

${ }^{12}$ In outline, the central government's accounting framework consists of the general account and 31 special accounts (e.g., for transfers to local administration or the social security system, or for dedicated expenditures
}

(continued...) 


\section{Boosting Productivity}

\section{Background}

\section{Ongoing initiatives aim to strengthen the supply side of the economy:}

- Downsizing the government: A recent law outlines inter alia the strategy for reforming government financial institutions (GFIs) as part of a broader plan (which includes the pending privatization of Japan Post) to reduce the government's role in financial intermediation and level the playing field. In addition, a "market-testing" law recently enacted opens up to private competitors the provision of some public services (job placement and some revenue collection).

- Product and labor market reforms: A strengthened antitrust law came into force in January 2006; steps to facilitate inward foreign direct investment (FDI) were approved in 2005; and a bill on shifting from price to income support in agriculture is under deliberation. Initiatives to exploit economies of scale in agricultural land use are also ongoing. Finally, measures to increase labor market attachment are in the works, including some to address high marginal tax rates for secondary wage earners. ${ }^{13}$

- More broadly, a host of regulatory reforms have been introduced in "Special Zones for Structural Reform" on a pilot basis, and some have been rolled out nation-wide.

\section{Policy Issues and Staff Views}

20. Deeper and broader structural reforms would lift growth prospects. Much has been accomplished in the government's agenda, especially in the corporate and financial sectors, but efforts could be redoubled in key areas. ${ }^{14}$ The payoff from a comprehensive approach could be substantial (Annex I).

- On labor markets, steps are needed to: encourage participation of women, marginalized youth, and older workers; clarify dismissal conditions; make corporate pensions more

such as on roads). Total outlays of special accounts, including inter-account transactions (e.g. with doublecounting), are about $¥ 460$ trillion compared to about $¥ 80$ trillion in the general account.

${ }^{13}$ Special deductions for spouses earning less than the primary wage earner have been reduced since 2006.

${ }^{14}$ See Going for Growth, OECD, 2006. 
portable (to enhance labor mobility); and balance employment conditions for regular and temporary workers. ${ }^{15}$

- On product markets, there is scope for further deregulating sheltered sectors (e.g., retail, network services); cutting agricultural protection; enhancing flexibility in zoning; and establishing independent regulators for network industries.

- On promoting Japan's integration with the world economy (which by the metrics of import penetration, inward FDI, and share of foreign workers is low) Japan could show ambition in the Doha Round - particularly in areas, such as agriculture, which could spur productivity. ${ }^{16}$ Participation in Economic Partnership Agreements (EPAs), designed with liberal rules of origin and complemented by reduced trade barriers for all partners, could also play a part in unlocking productivity gains.

21. The reform momentum should be maintained. The electoral cycle or reform fatigue may cause slow implementation or backsliding. However, the favorable conjuncture and the potential boost to fiscal consolidation from higher growth put a premium on sustained efforts.

\section{The Authorities' Views and Policy Intentions}

22. The authorities agreed that further structural reforms are needed. With regard to the areas highlighted by the mission, their plans include:

- On labor markets, the authorities are considering clarifying the terms of employment, and liberalizing dismissals, including compensated layoffs. More broadly, steps to encourage labor force participation of women and marginalized workers by (for example) improving the availability of childcare and training are under consideration, as are measures to reduce the benefit disparities between regular and temporary workers.

- On product markets, the authorities noted that a new law imposing zoning restrictions on large-scale retailers is intended to preserve the vitality of city centers rather than roll back past deregulation of the distribution sector. Liberalization of the energy sector also continues. As regarded the role of independent regulators, the authorities saw the current arrangement as working well, particularly in the telecommunications sector.

\footnotetext{
${ }^{15}$ Current regulations favor employment of some non-regular workers, for example by excluding them from social insurance coverage. Limited job tenure reduces firms' incentives to train them, depressing aggregate productivity.

${ }^{16}$ Japan's commitment to move to duty- and quota-free access for LDCs on at least 97 percent of tariff lines by 2008 (as agreed at the 2005 WTO Hong Kong Ministerial) would be most beneficial with broad agricultural access.
} 
- On promoting Japan's integration with the world economy, the authorities stressed that Japan remains fully committed to a successful conclusion of the Doha Round. While acknowledging risks from the proliferation of EPAs, Japan seeks to ensure that its regional trade strategy complements the multilateral system. Some agricultural products were included in the Mexico EPA, and inclusion could be more extensive in the ASEANwide agreements. (The authorities noted that Japan is the largest importer of agricultural products and food security is a concern.) At least two EPAs under negotiation consider freer movement of workers. To promote inward FDI, provisions that will facilitate foreign acquisition of domestic companies (so-called "out-in" M\&A) are scheduled to take effect in 2007.

\section{At the same time, their near-term priorities relate to education,} broadcasting/communications, and immigration. Steps under consideration include: in education, allocating school funds more closely in relation to the number of students; in broadcasting/communications, facilitating the use of digital technology and liberalizing entry to the broadband internet market; and in immigration, relaxing visa requirements for skilled workers and the intra-company transfer of foreign personnel.

\section{Financial Sector Policy Challenges}

With monetary normalization, improved balance sheets, and GFIs downsizing, important shifts are afoot in financial markets. Investors are becoming less defensive, while abundant corporate liquidity points to robust physical and financial investment ahead. At the same time, banks and nonbank financial institutions are entering new business lines, expanding overseas and into newer markets like credit derivatives. In this evolving landscape, key financial sector issues relate to the impact of rising interest rates, the adequacy of risk management systems, and the implications of GFI reform.

\section{Background}

24. With a favorable outlook and stronger balance sheets, financial institutions are set to play a more vigorous role in financial intermediation.

- Financial markets are normalizing: Short- and long-term interest rates have edged up since quantitative easing ended, and will rise further as inflation expectations take hold and the BoJ shifts to a more neutral stance (Figure 2). Equity markets have been on an upward trend since 2003, notwithstanding recent retrenchment. At the same time, credit spreads have remained tight for higher-rated corporations. Resumed bank lending implies a strengthening monetary transmission mechanism.

- Defensive post-bubble financial postures are changing: Retail and institutional investors are gradually shifting toward risk assets (including foreign assets). Banks and nonbank financial institutions are diversifying, expanding overseas and into new markets (such as 
those for syndicated loans and credit derivatives), spurred by deregulation and cleaner balance sheets. ${ }^{17}$ Going forward, banks are well positioned to provide "growth capital" to the economy.

- GFI reform is underway: Following passage of bills to privatize Japan Post in October 2005, the government announced plans to consolidate GFIs and reduce the ratio of their loans to GDP by half in three years, to create further space for private banks to expand (Box 5).

- Regulation is adapting:

- The official framework to deal with these changes is the December 2004 Program for Further Financial Reform (PFFR). This program shifted the focus of policy from stabilization to revitalization, although remaining balance-sheet problems are not being neglected (in particular, the impact of deferred tax assets on the capital of major banks; NPLs at regional banks; and bloated GFI balance sheets). The PFFR aims to promote competition in the financial system, as well as to support improvements in risk management and core profitability at banks.

- More recently, the authorities have taken steps to foster the development of capital markets. A new Financial Instruments and Exchange Law (enacted in June 2006) enhances investor protection, improves disclosure of listed companies, and strengthens the independence of self-regulatory bodies at financial exchanges.

\section{Policy Issues and Staff Views}

\section{Unfolding changes in financial markets hold out the promise of more efficient} financial intermediation (domestically, regionally, and globally) but call for regulatory vigilance. Issues relate to banks' efforts to boost core profits, balance sheet exposures to market risk, the adequacy of risk management systems, and the implications of GFI reform.

- New financial activities present challenges for regulation and risk management. For example, major banks' fee income from new financial services quadrupled in FY20012004 and credits to the Asian and Pacific region have expanded rapidly (Box 6) ${ }^{18}$ Both

\footnotetext{
${ }^{17}$ Banks have been allowed to broker equity sales since December 2004 and to offer a wide range of financial products through their branches since April 2006.

${ }^{18}$ The Selected Issues paper examines the re-emergence of Japanese banks' activities in Asia.
} 


\section{Box 5. Reform of Government Financial Institutions (GFIs)}

Following the passage of legislation to privatize Japan Post, the government designed its basic plan scale back remaining GFIs in late $\mathbf{2 0 0 5}$ as a part of a broad reform program towards a small and efficier government. ${ }^{1}$ Subsequently, the government has tailored legislation that includes:

- A quantitative target to reduce the ratio of GFI lending to GDP by one-half in three years, and restricting GFIs to financing small- and medium-sized enterprises (SME) and international operations deemed crucial to the national interest. The plan also calls for a move from direct lending to partial guarantees, securitization, and indirect loans.

- $\quad$ Privatization of the SCB and the DBJ within 5-7 years. The abolishment of the JFCME and a merger of four GFIs (SME,

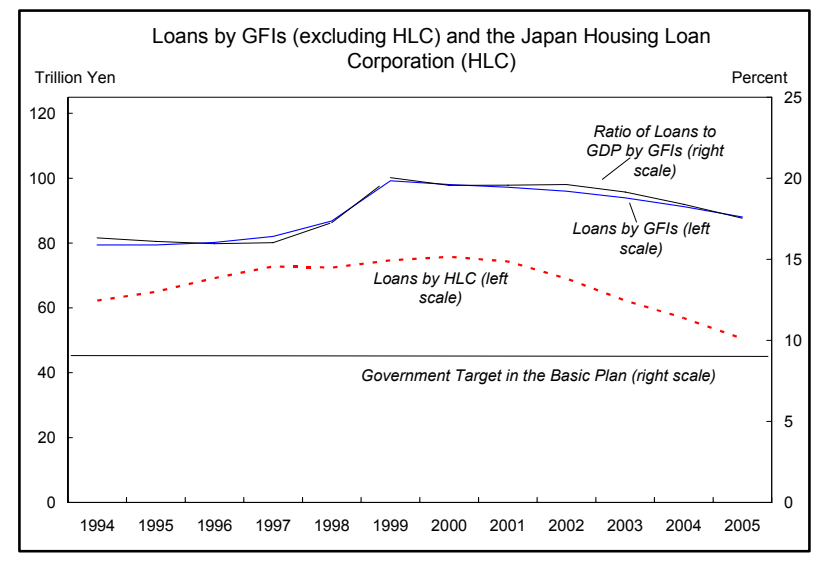
agricultural, and international financing) will take place in FY 2008, with the other one being consolidated later.

- Steps to contain possible adverse effects on agents currently receiving GFI financing and transitional measures during the shift to financial self-reliance of the privatized GFIs, as well as continued "market testing" to identify and rationalize redundant GFI functions.

The reform of Japan's GFIs is a welcome step to downsizing public involvement in financial intermediation. Indeed, growth in private housing loans following the downsizing of the public Housing Loans Corporation as well as major progress in the basic plan-privatizing two institutions overlapping with private institutions - suggest that the benefits from the GFI restructuring could be sizable if the plan is successfully carried out. Key issues are to enhance transparency of costs incurred by the new GFI while leveling its playing field with private intuitions, and to elaborate a transitional plan toward privatizing some additional GFIs. More specifically;

- New GFI: Sound corporate governance (including independence from government intervention on specific lending activities) and enhanced disclosure for the new GFI is a necessary element of the reform plan to constantly check its activities through "market testing" as envisaged in the basic plan; undue financial support and regulatory forbearance would obscure the fiscal cost and should be avoided; and, budgetary and operational firewalls between business and agriculture finance are desirable to insulate small-business and other borrowers from shocks from agricultural sector.

- Privatized Institutions: The profitability of the privatized institutions needs to be ensured before privatization to avoid continued loss making and related fiscal costs; government equity in these GFIs should be eventually fully divested to private shareholders and any windfall gain should be saved to reduce the government deficit. Meanwhile, operational independence from the government should be guaranteed.

\footnotetext{
${ }^{1}$ The government initiated its reforms to reduce the scope and improve efficiency of GFI activity in 2001 when it decided to limit activities of the Japan Housing Loan Corporation to securitize housing loans originated in the private sectors. The basic plan focuses on the remaining eight GFIs, namely, the National Life Finance Corporation, Japan Finance Corporation for Small and Medium Enterprise, the Shoko Chukin Bank (SCB), the Development Bank of Japan (DBJ), the Okinawa Development Finance Corporation, the Japan Agriculture, Forestry's and Fisheries Finance Corporation, the Japan Bank for International Cooperation, and the Japan Finance Corporation for Municipal Enterprises (JFCME).
} 


\section{Box 6. Overseas Activities of Japanese Banks}

Japanese banks have renewed their efforts to expand overseas, particularly in Asia, in recent years, as nonperforming loans have been significantly reduced. In the last three years, Japanese banks' outstanding external credits have, on average, grown annually at a 14 percent pace. Except for offshore centers, the Asia/Pacific region (excluding Hong Kong SAR and Singapore) is the most rapidly growing credit destination. ${ }^{1}$ Although the Asia/Pacific share is still small — about onesixth of the U.S., Canada and Europe sharesit has increased steadily since 2002, while others (notably shares of the U.S. and Canada) have decreased.

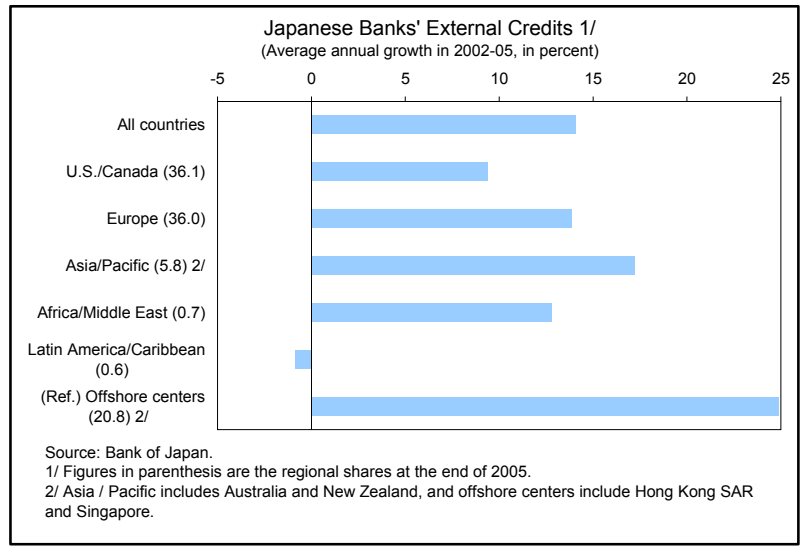

Recent expansion plans by Japanese banks appear to be focused on providing loans, derivatives, and cash management services to Japanese companies operating in Asia. China, South Korea, and major South East Asian countries, and more recently, India and Vietnam are the main countries of focus. The strategy is similar to the business model employed by German and other industrial-country banks to service their corporate clients worldwide. In addition, there is growing interest among Japanese banks in expanding their presence in specific domestic markets, such as banking services to non-Japanese clients, syndicated loan arrangements, and structured finance products for local investors.

Enhancing the ability of Japanese banks to provide services to Japanese and nonJapanese clients in Asia would improve their still-low profitability at home, as well as diversify credit risk. In fact, the Asia/Pacific region has recently been a source of relatively stable and high profits for Japanese banks, along with North and Latin America, where their main focus is on investment banking (e.g., securities investment and fee-related businesses). The Asia/Pacific region accounts for about 30 percent of total overseas profits in 2005 but a much smaller share of outstanding overseas credit.

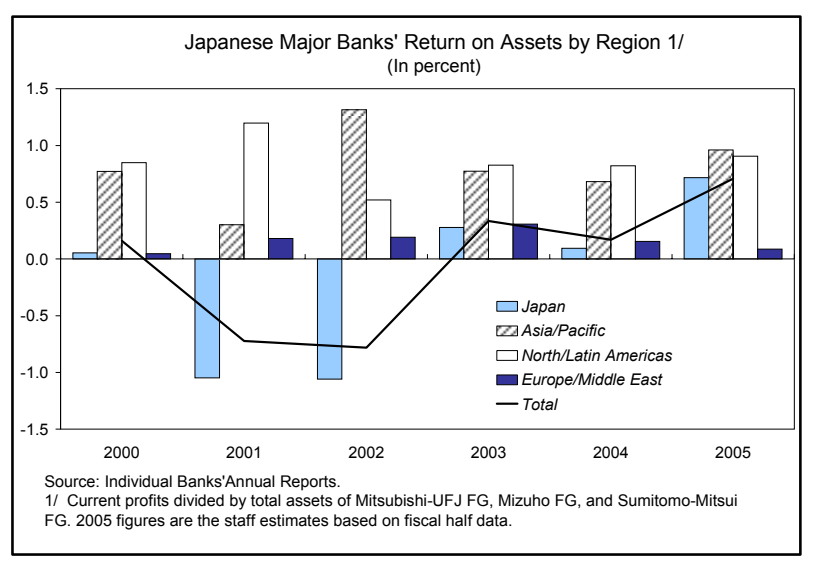

A continuation of this trend of allocating more assets to Asia would improve profit levels and diversify both profit sources and credit risks, but could also involve risks. Diversification is consistent with Japanese banks' current overseas strategy, as well as with Japanese supervisory policies and the Basel II principle. At the same time, the risks in these exposures may not be fully understood, and bear watching.

${ }^{1}$ Cayman Islands represents 72.7 percent of these credits to offshore centers, where such credits are largely related to special purpose vehicles and hedge funds, benefiting from tax haven treatment, followed by Singapore (5.7 percent), Panama (5.5 percent), and Hong Kong SAR (5.2 percent). 
developments could raise profits, but also introduce new risks. The expansion of credit derivatives (which allow transfer of credit risks to non-bank entities) and structured finance products (e.g., collateralized debt obligations) is helping to diversify risks, but may have systemic implications as the market grows.

- The impact of rising interest rates and asset repricing on financial institutions and corporates bears watching. Though higher rates and a steeper yield curve support bank profits over a longer horizon, lending rates usually lag increases in bond rates. Rising long-term rates may cause capital losses, although they should be manageable. ${ }^{19}$

- GFI reform plans would go some way to level the playing field in banking, but much depends on the details of implementation. Planned reforms would need to ensure profitability and stability of the institutions affected, and would need to avoid undue financial support or regulatory forbearance.

\section{The Authorities' Views and Policy Intentions}

\section{The authorities agreed that the priority is to continue revitalizing the financial} system.

- On the banking sector, the authorities acknowledge that major banks' core profits remain low despite high net income, and agree that the priorities are improving banks' profitability and risk management. They noted that, in the search of new business models, banks are expanding into fee-earning activities, but the effects of recent deregulation are yet to be seen.

- The authorities agree that risks from rising interest rates are manageable, both because of improved bank capital and reduced duration of banks' exposures.

- The authorities are preparing to strengthen oversight of risk management as well as risk management systems at banks, in the context of Basel II (Japan is represented in the Basel Committee). The Basel II framework is to be introduced by end-March 2007; corresponding revisions to capital adequacy regulations and supervision guidelines were made in March 2006, with other revisions to be finalized soon. Regarding credit derivatives, the domestic market is relatively small and risks are limited.

- The authorities are making efforts to promote the development of securities markets, particularly through the Financial Instruments and Exchange Law. Effective enforcement of the law will also enhance investor protection. The Tokyo Stock Exchange is expanding

\footnotetext{
${ }^{19}$ A BoJ report shows that losses that would result from a yield curve steepening with a 100-basis point rise in long-term yields amount to only about 5 percent of Tier 1 capital for major banks as of end-March 2005.
} 
its trading capacity this year, and will introduce a new system by 2009 . In addition, the new law allows the stock exchange to set up an independent self-regulatory body.

- As for the GFIs, implementation details for the reform plans will be fleshed out later this year. In principle, the reform opens up business opportunities for private institutions.

\section{INTERNATIONAL IMPLICATIONS OF JAPAN's RECOVERY AND POLICIES}

Japan's economic resurgence has yielded significant benefits for the region and the rest of the world economy. Underlying fundamentals suggest that the yen should appreciate over the medium term and the external surplus should shrink. Fiscal consolidation may slow these adjustments, but this is a reasonable price to pay: fiscal stability is in Japan's and the world's long-term interests. More broadly, Japan has a well-recognized role to play in a cooperative effort to mitigate the risk of a disruptive adjustment of global imbalances.

\section{Background}

\section{Japan's expansion is having positive effects regionally and globally:}

- Supporting growth: Since 2002, Japan's real GDP has risen at a 21/4 percent annual rate, adding on average about $1 / 4$ percent points to global growth each year.

- Expanding trade: Since 2002, Japan's imports of goods and services have increased by some $\$ 150$ billion - an increase of nearly 35 percent in dollar terms. Exports have grown briskly as well, with the expanding international supply chain contributing to rising trade integration between Japan and other Asian countries.

- Narrowing global imbalances: After rising in 2004, the current account imbalance shrank modestly in 2005, notwithstanding a jump in income flows from Japan's large creditor position as overseas FDI matured.

- Swelling FDI outflows: Since 2002, net direct investment outflows rose by over 40 percent in dollar terms.

- Limited adverse regional spillovers from yen weakening: Asian countries (except Korea) compete with Japan in third markets to only a limited extent. In addition, the weaker yen cheapens capital imports for other Asian countries.

\section{Derivatives prices imply only moderate risk of large near-term yen moves.}

- Implied volatility — a measure of market uncertainty — on yen/dollar option contracts remains below past peaks at short maturities, suggesting limited concerns that unwinding 
of carry trades could prompt appreciation. ${ }^{20}$

- That said, the term structure of implied volatilities slopes upward, suggesting slightly greater uncertainty about exchange-rate moves over longer horizons.

- The risk of a rapid unwinding of carry trades as monetary policy normalizes seems moderate. Forward yen interest rates remain low, compared (for example) to U.S. dollar forward rates, and market participants see limited leverage in carry trades.

\section{Over the medium term, however, underlying macroeconomic fundamentals} imply that the yen should appreciate. The cyclical recovery, as well as longer-term trends in population aging and broad-based productivity gains, would be associated with a higher real exchange rate and a narrowing of the current account. Consistent with this scenarioand subject to large margins of statistical uncertainty - estimates by the IMF's Consultative Group on Exchange Rates suggest that the yen could appreciate in real effective terms over the medium term; this would likely take place in the context of multilateral adjustment in partner-country currencies. Such exchange rate and current account adjustments are apt to occur notwithstanding the headwinds from fiscal consolidation-crucial for long-term sustainability - and further reductions in home-bias by Japanese investors, which may slow the medium-term appreciation.

\section{Policy Issues and Staff Views}

30. Japan, along with other countries, has a key role to play in contributing to a smooth resolution of global imbalances. In this context, accelerated structural reforms to boost domestic demand are a key ingredient in a multilateral strategy. For example, a combination of an additional $1 / 4$ percent per year in productivity growth, along with a moderate rise in female labor force participation, could raise potential GDP growth by $1 / 2$ percent per year - a figure within the range of estimated gains from product and labor market reforms. Simulations using the Global Economic Model suggest that under this scenario, the current account would fall over the near term by some $1 / 3$ percent of GDP relative to the baseline. ${ }^{21}$ Under a scenario that incorporates both stronger productivity

\footnotetext{
${ }^{20}$ Implied volatility is an estimate of market uncertainty about future asset-price moves extracted from option prices. If investors were risk-neutral, implied volatility would be equal to the market estimate of the standard deviation of asset price changes.

${ }^{21}$ The baseline and "structural reform" scenarios assume the authorities' program of $1 / 2$ percent of GDP consolidation per year. The "structural and fiscal reforms" scenario assumes the staff's recommendation of $3 / 4$ percent of GDP consolidation per year. These simulations are reported in the background paper for last year's Article IV consultation (IMF Country Report No. 05/272 at www.imf.org). The assumed annual payoff of $1 / 4$ percent is at the conservative end of the range of estimates in the literature. If the payoff were larger - or if the rise in prospective income reduced precautionary savings (which is not accounted for in the model) - the fall in the current account balance could be larger and more sustained.
} 
growth and the staff's recommended path of fiscal consolidation (an additional $1 / 4$ percent of GDP per year), higher growth partly offsets the effects of fiscal consolidation on the external surplus. $^{22}$ These results do not assume implementation of the "agreed strategy" outside Japan - notably, fiscal consolidation in the United States, greater exchange rate flexibility in emerging Asia, and pro-growth reforms in Europe. As part of a concerted policy effort, a vigorous reform program in Japan would help reduce the risk of a disorderly adjustment of global imbalances that could entail slower world growth and sharp exchange rate movements.

\begin{tabular}{|c|c|c|c|c|c|c|c|c|}
\hline \multicolumn{9}{|c|}{$\begin{array}{l}\text { Effects of Structural and Fiscal Reforms } \\
\text { (Percentage point deviation from baseline) }\end{array}$} \\
\hline & \multicolumn{4}{|c|}{ Structural Reforms } & \multicolumn{4}{|c|}{ Structural and Fiscal Reforms } \\
\hline & 2006 & 2008 & 2011 & 2016 & 2006 & 2008 & 2011 & 2016 \\
\hline \multicolumn{9}{|l|}{ Japan } \\
\hline Real GDP (level) & 0.0 & 0.3 & 1.5 & 3.6 & -0.2 & -0.2 & 0.7 & 2.5 \\
\hline Current account (percent of GDP) & -0.3 & -0.3 & 0.0 & 0.1 & -0.1 & 0.5 & 0.8 & 0.7 \\
\hline Government debt (percent of GDP) & 0.0 & -1.1 & -1.9 & -4.9 & 0.3 & -0.7 & -5.8 & -17.8 \\
\hline \multicolumn{9}{|l|}{ United States } \\
\hline Real GDP (level) & 0.0 & 0.0 & 0.0 & 0.0 & 0.0 & 0.1 & 0.0 & 0.0 \\
\hline Current account (percent of GDP) & 0.0 & 0.1 & 0.0 & 0.0 & 0.0 & -0.1 & -0.2 & -0.2 \\
\hline \multicolumn{9}{|l|}{ Euro Area } \\
\hline Real GDP (level) & 0.0 & 0.0 & 0.0 & 0.0 & 0.0 & 0.0 & 0.0 & 0.0 \\
\hline Current account (percent of GDP) & 0.0 & 0.0 & 0.0 & 0.0 & 0.0 & 0.0 & 0.0 & 0.0 \\
\hline \multicolumn{9}{|l|}{ Emerging Asia } \\
\hline Real GDP (level) & 0.1 & 0.1 & 0.0 & 0.0 & 0.0 & -0.1 & -0.1 & 0.0 \\
\hline Current account (percent of GDP) & 0.0 & 0.0 & 0.0 & 0.0 & 0.0 & 0.0 & 0.0 & 0.0 \\
\hline \multicolumn{9}{|l|}{ Memorandum Items } \\
\hline \multicolumn{2}{|l|}{$\begin{array}{l}\text { Change in Potential Growth in Japan } \\
\text { Of Which: }\end{array}$} & 0.3 & 0.5 & 0.5 & & 0.3 & 0.5 & 0.5 \\
\hline TFP & & 0.2 & 0.3 & 0.3 & & 0.2 & 0.3 & 0.3 \\
\hline Labor Input $1 /$ & & 0.1 & 0.2 & 0.2 & & 0.1 & 0.2 & 0.2 \\
\hline Change in female participation rate in Japa & & 1.0 & 2.8 & 5.1 & & 1.0 & 2.8 & 5.1 \\
\hline
\end{tabular}

31. A return to a more neutral monetary stance is likely to have had some effect on global liquidity conditions. The unwinding of yen carry trades has had an impact on selected markets outside Japan, although factors specific to those markets were at play. More generally, heightened expectations that BoJ accommodation will be reduced during 2006 have had limited effects in international markets. This may reflect clear communication of the intent to maintain accommodative conditions, which has smoothed ripples in financial markets.

\section{The policy of a market-determined exchange rate remains appropriate. Under} the likely scenario of a gradual adjustment in the exchange rate, intervention would not be

\footnotetext{
${ }^{22}$ This second scenario does not show any additional positive effect of further fiscal consolidation on potential growth, because it entails only a modestly more ambitious schedule of deficit reduction compared with both the first alternative scenario and the baseline - an additional $1 / 4$ percentage point of GDP per year over five years.
} 
needed in a setting where deflation pressures have lifted, the monetary policy transmission mechanism has strengthened, and corporations are in robust shape.

\section{The Authorities' Views and Policy Intentions}

33. The authorities agreed that a strategy involving a number of countries is needed to promote a smooth rebalancing of world demand. While the near-term risks of disorderly adjustment seem limited - and interest differentials would probably lend support to the U.S. dollar in the short run-imbalances add uncertainty to the global economy in the medium run.

\section{However, undue emphasis should not be put on adjustments in exchange rates.} Heavy emphasis on exchange rate adjustments could trigger disruptive movements in major currencies. Instead, the focus should be on rebalancing world demand through fiscal consolidation in the United States complemented by structural reforms to boost domestic demand in Europe and Japan. In addition, a renewed push at the WTO to liberalize trade in services may pave the way for greater U.S. exports.

35. There are also questions about the size of the needed adjustment. The authorities considered the sustainable current account deficit for the U.S. may have risen in tandem with global savings and productivity growth, to perhaps as high as $4 \frac{1}{2}-5$ percent of GDP. Thus, the needed adjustment might be moderate.

\section{The authorities also saw limited risks in a disorderly unwinding of yen carry}

trades. Data remain scant, but to the extent that carry trades are defined narrowly as speculative positions of hedge funds (for example, proxied by IMM contracts), the fact that these institutions have recently been able to build up and wind down such exposures smoothly suggests that there are limited risks of a systemic problem.

37. Japan's exchange rate policy remains unchanged. As stated in a recent G-7 communiqué, the yen exchange rate should reflect economic fundamentals, and the authorities will take appropriate action as necessary to counter disorderly movements.

\section{Staff Appraisal}

38. Japan's post-bubble legacies have essentially been resolved and deflation has ended. Fragilities in the corporate and financial sector have been dealt with, supporting a rebound in investment. Improving labor markets and disposable incomes have helped broaden the expansion to the household sector. These developments have resulted in a prolonged upswing at a rate above potential - and growth now grounded on private domestic demand. In addition, consumer prices now seem likely to continue rising, and the risk of a deflationary relapse has receded. 
39. The post-deflation era brings new challenges. Monetary policymakers are adapting to the operational and communication trials of an environment with two-way inflation risks. Fiscal policy is beginning to rein in budgetary imbalances and make room for the demands of population aging. Structural reforms aim at boosting productivity and preserve living standards in the context of a shrinking labor force. Financial sector reforms are laying the groundwork for improving the efficiency of intermediation while safeguarding financial stability. Progress is being made on all these fronts, but more remains to be done to secure strong non-inflationary growth over the medium term.

\section{The end of deflation and the smooth transition out of quantitative easing} represent milestones for monetary policy. The sizeable reduction in excess reserves without undue volatility in financial markets reflects deft operations and communications by the BoJ. Clear communication has also helped to defuse market concerns that the end of quantitative easing portends a sharp withdrawal of stimulus. In the near term, the policy stance should remain accommodative, allowing inflation expectations to drift up.

41. The new monetary framework is well suited to the new environment. The framework clarifies how the BoJ will approach monetary policy in the post-deflation environment and, as such, is a welcome improvement in transparency. At the same time, it allows appropriate flexibility for the BoJ to respond to a range of short and long-term risks.

\section{That said, steps to elaborate further various aspects of the monetary framework} could help to guide market expectations and bolster policy credibility. In particular, as regards the zero lower bound on the "understanding of price stability," clearly explaining the risks associated with near-zero inflation could help markets to form appropriate expectations about the conduct of policy. In addition, the range (or its floor) could adjust upwards over time, in the context of the periodic reviews. A higher floor would signal the desirability of a buffer against deflationary shocks.

\section{Considerable progress has been made in fiscal consolidation without holding} back the expansion. The long cyclical upswing has contributed to revenue buoyancy and made it easier to restrain spending, but discretionary measures - curbing public works, reforming social security, and rolling back past tax cuts - have played an important role as well. The fact that consolidation has occurred without noticeably dampening economic momentum or worsening deflationary pressures suggests that an ambitious approach to stabilizing public finances need not derail the expansion.

44. As is well recognized, the task ahead remains large. In this connection, the authorities' commitment to continue with fiscal consolidation is welcome. So are recent steps to strengthen their plan and make it more concrete. Given the strength of the expansion, a somewhat more front-loaded and ambitious adjustment than envisioned by authorities would be appropriate, as it would stabilize the debt and buy insurance against unanticipated fiscal or 
economic shocks. It would also bolster the credibility of the authorities' fiscal adjustment program, helping to limit the risk of rising real interest rates as the expansion matures.

45. Progress has also been made in structural reforms. Indeed, the strong expansion may in part reflect the payoff from vigorous financial and corporate sector restructuring in the past. Going forward, steps to downsize government, rationalize labor and product market regulation, and liberalize trade should over time lift productivity further.

46. Accelerating structural reform would pay additional dividends to Japan and the world. Stronger underlying growth would facilitate fiscal consolidation while helping to support living standards in the face of population aging. It would also bolster world growth and support a more balanced pattern of global demand, which along with actions in other countries would help to promote an orderly resolution of global imbalances. For all these reasons, it would be crucial to maintain an ambitious reform program.

\section{Further financial sector reforms will also help to sustain non-inflationary} growth over the medium term. Steps underway to reduce the government's role in intermediation, streamline and clarify securities regulation, and bolster financial risk management will help to safeguard the stability of the financial system while improving its efficiency. They will also help to promote the further development of securities markets, providing an additional source of financing to reduce the risk of a credit crunch in the event of banking system stress.

48. It is recommended that the next Article IV consultation take place on the standard 12month cycle. 
Figure 1. Japan: Output, Inflation, Corporations and Banks
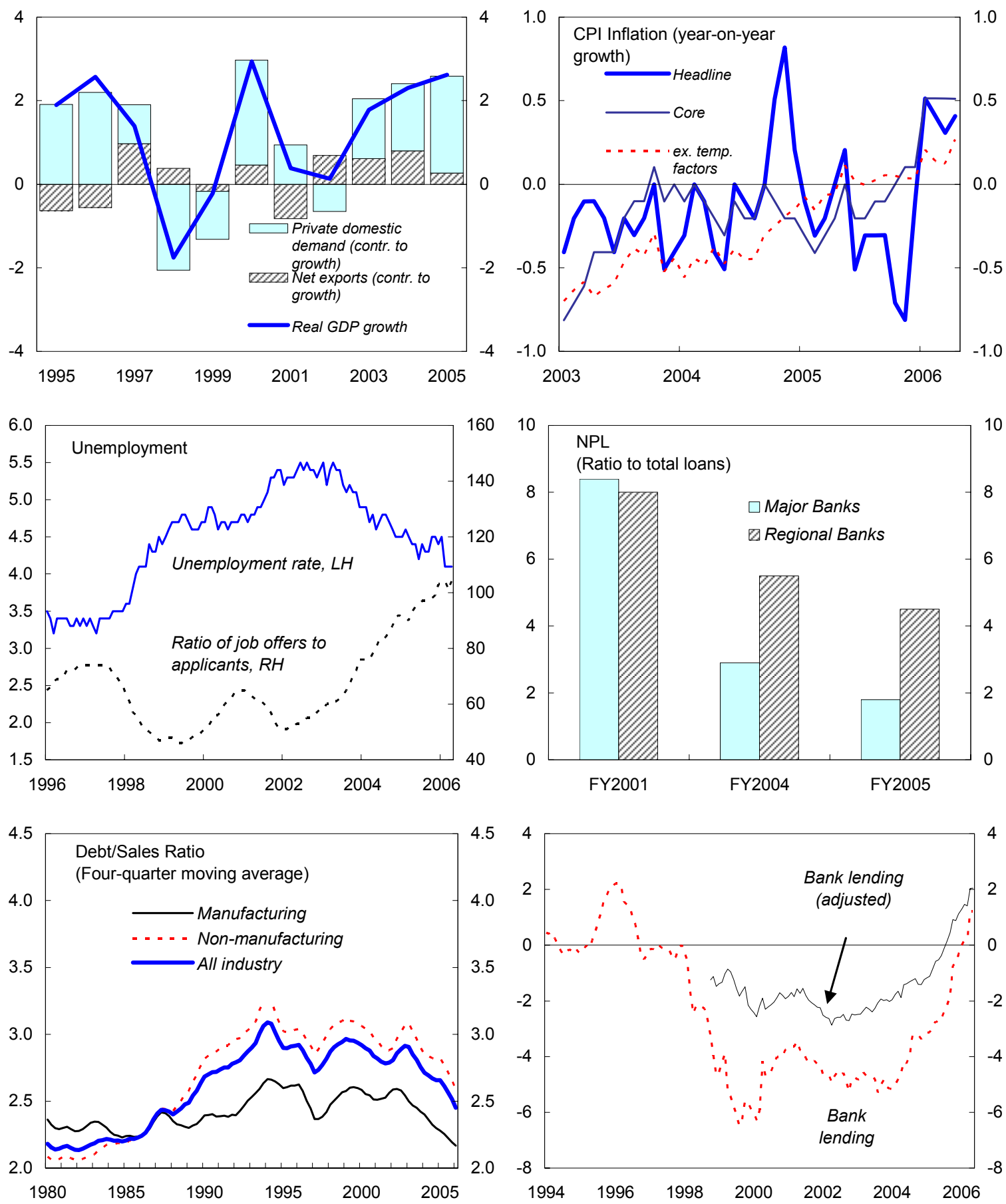

Sources: CEIC; Nomura; FSA; Ministry of Finance. 
Figure 2. Japan: External Sector, Monetary and Fiscal Policy
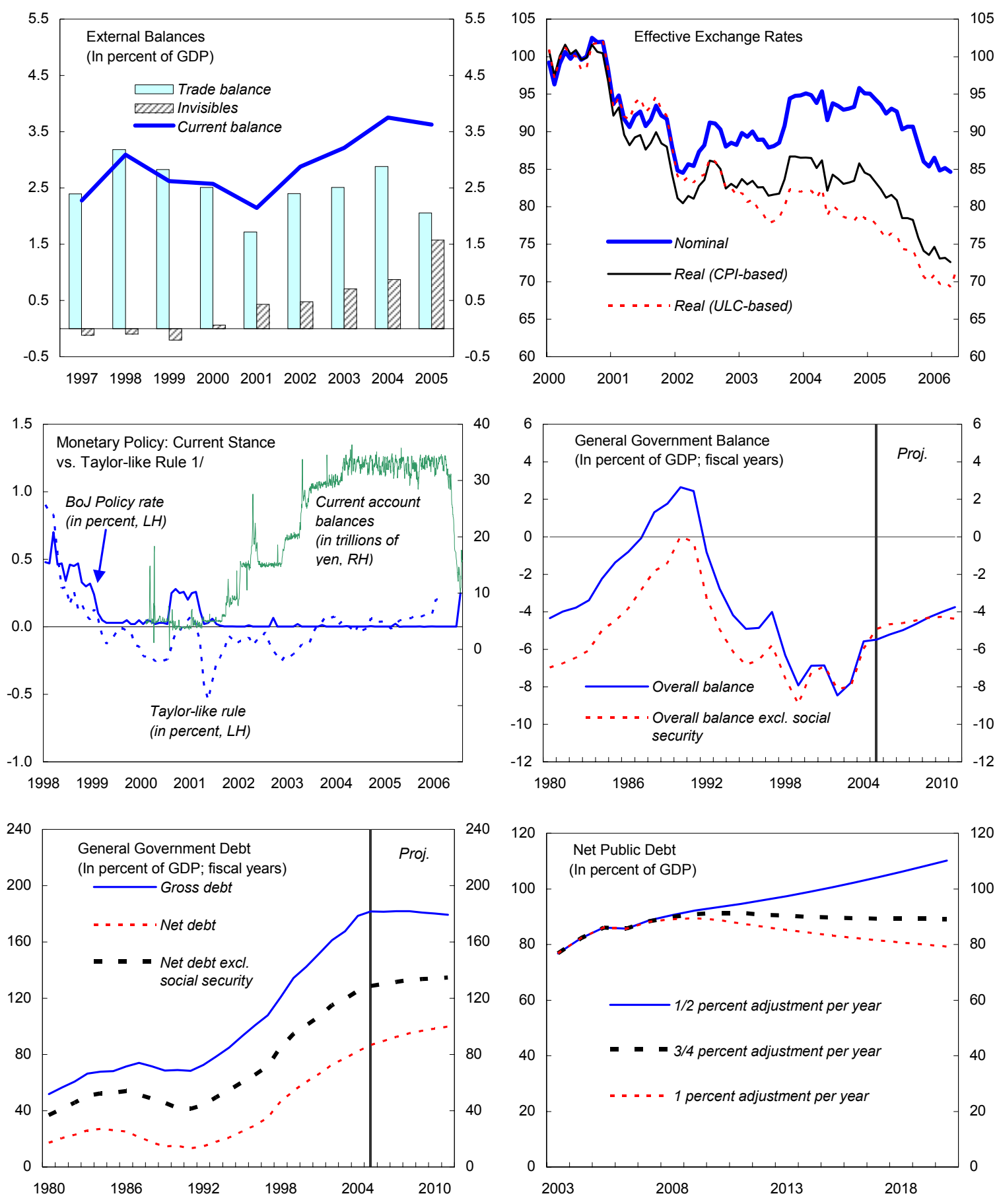

Sources: CEIC; Nomura; INS, Information Notice System; Ministry of Finance; Bank of Japan; and staff calculations.

1/ The Taylor-like rule ignores the zero bound on interest rates. Based on staff estimates, it assumes a dynamic neutral real rate and weights for inflation and the output gap in a 21/4 to 1 ratio. A 1 percent inflation reference value is also assumed. 
Figure 3. Japan: Financial Markets
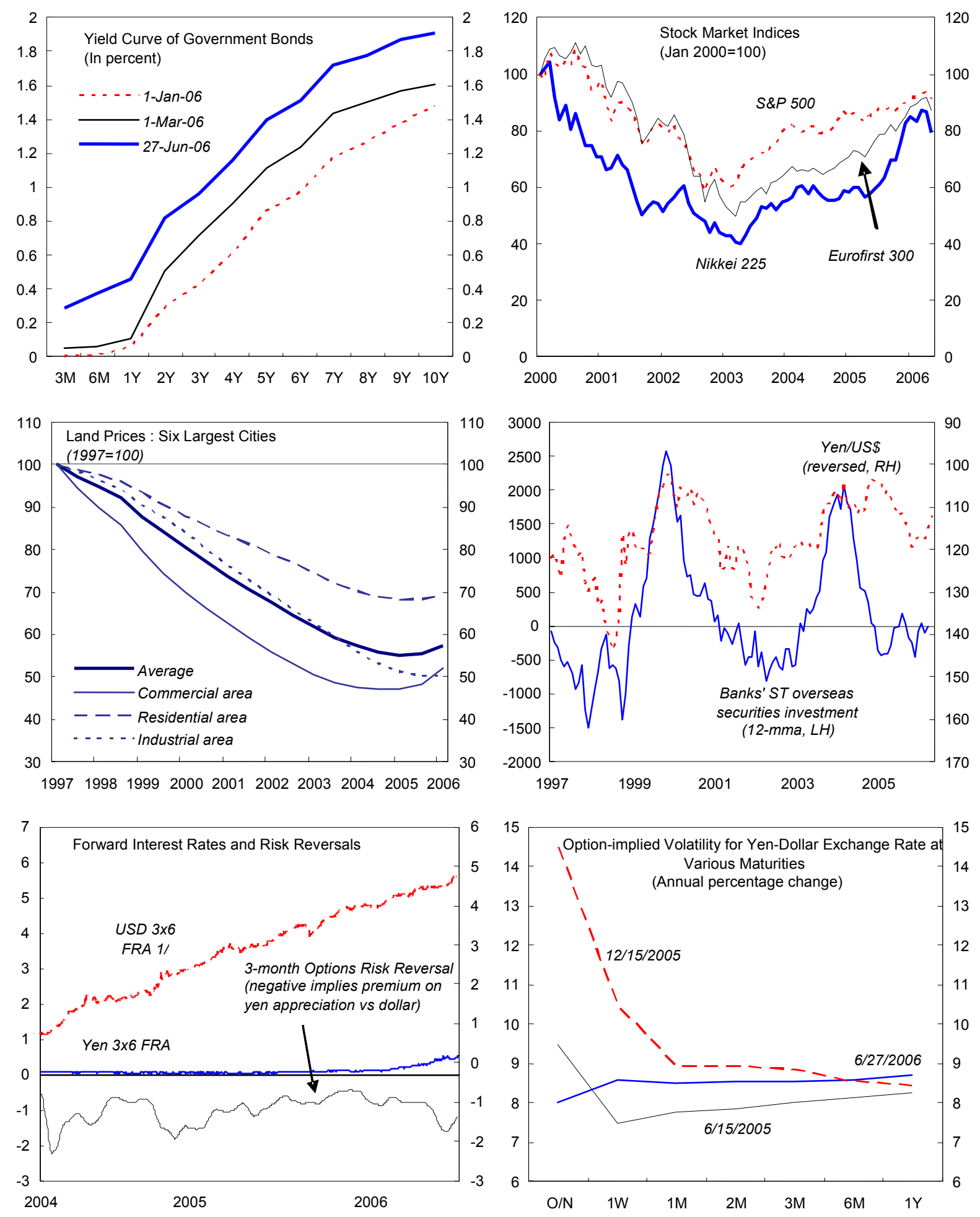

Sources: Tullet Prebon; Bloomberg; CEIC; Nomura database; Reuters.

$1 / 3 \times 6$ FRA=3-month maturity forward rate agreement, beginning in 3 months. 
Table 1. Japan: Selected Economic Indicators, 2002-2007

Nominal GDP: US\$4,571 billion (2005)

Main exports (percent of total, 2005): electrical machinery (22), manufacturing (11)

Unemployment rate (2005): 4.4 percent

FDI (2005): $\$ 3.3$ billion

Public debt, gross (2005): 175.4 percent of GDP

Foreign public debt (2005): 4.9 percent of total public debt

Population: 127.7 million (2005)

GDP per capita: US $\$ 35,795(2005)$

Quota: SDR 13,312.8 million

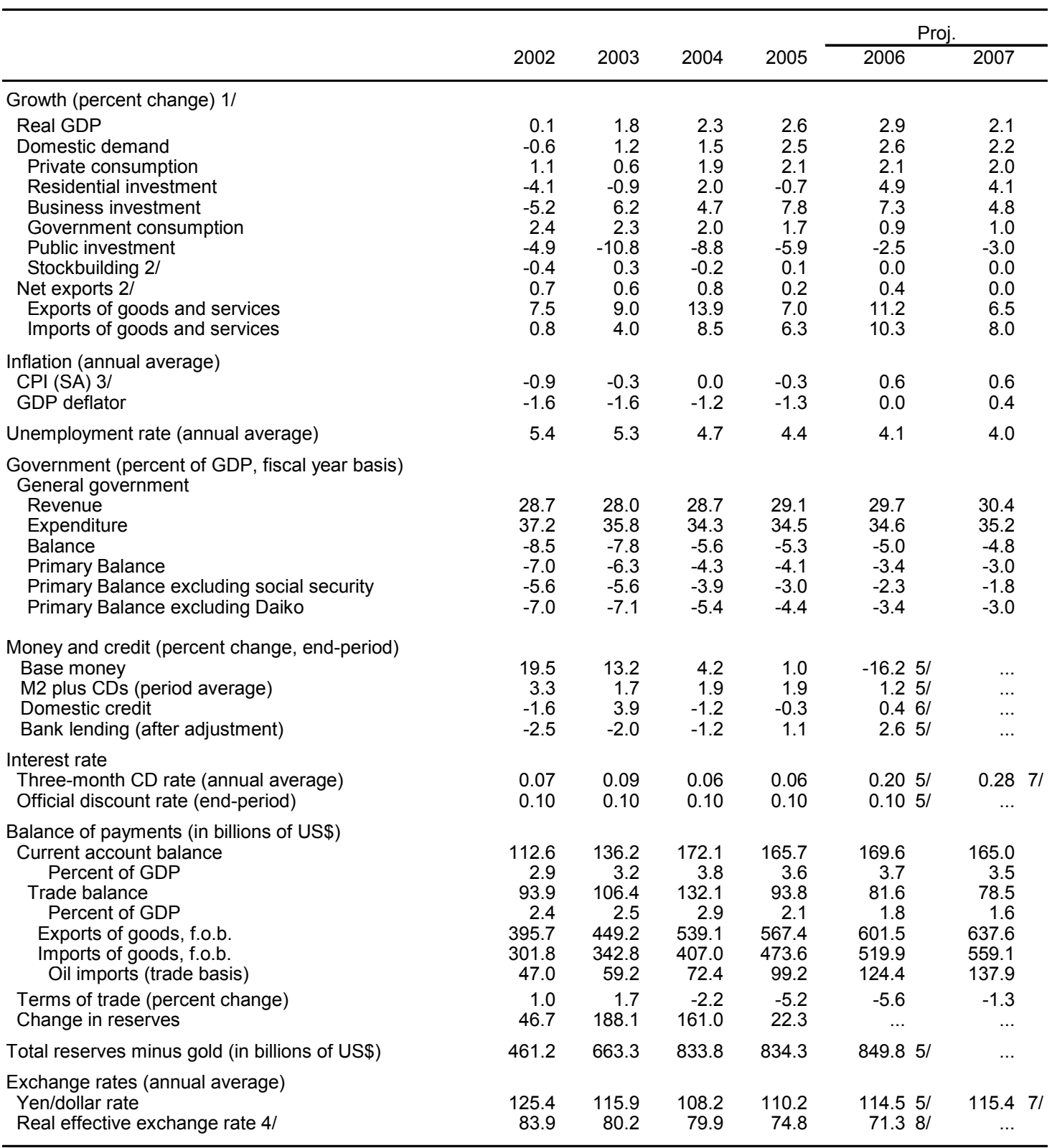

Sources: Global Insight, Nomura database; IMF, Competitiveness Indicators System; and Fund staff estimates and projections as of June 19, 2006.

$1 /$ Annual growth rates and contributions are calculated from seasonally adjusted data.

2/ Contribution to GDP growth.

$3 /$ Annual growth rates are calculated from annual averages of monthly data.

4/ Based on normalized unit labor costs; $2000=100$.

5/ June 2006

6/ April 2006

7/ July $13,2006$.

8/ May 2006 
Table 2. Japan: General Government Operations, 2000-2006 1/

(In percent of GDP)

\begin{tabular}{|c|c|c|c|c|c|c|c|}
\hline & 2000 & 2001 & 2002 & 2003 & 2004 & $\begin{array}{c}2005 \\
\text { Est. }\end{array}$ & $\begin{array}{c}2006 \\
\text { Proj. }\end{array}$ \\
\hline & \multicolumn{7}{|c|}{ (Fiscal year) } \\
\hline Total revenue & 30.0 & 30.3 & 28.7 & 28.0 & 28.7 & 29.1 & 29.7 \\
\hline Taxes and fines & 17.7 & 17.5 & 16.2 & 15.7 & 16.4 & 16.7 & 17.1 \\
\hline Social security premiums & 10.1 & 10.5 & 10.6 & 10.5 & 10.5 & 10.7 & 10.8 \\
\hline Property income & 2.0 & 1.9 & 1.7 & 1.5 & 1.5 & 1.6 & 1.5 \\
\hline Total expenditure & 36.8 & 37.1 & 37.2 & 35.8 & 34.3 & 34.5 & 34.6 \\
\hline Current & 29.9 & 31.0 & 31.2 & 31.0 & 30.9 & 30.8 & 31.0 \\
\hline Consumption & 11.5 & 11.9 & 11.9 & 11.9 & 11.8 & 11.7 & 11.5 \\
\hline (less) Depreciation & -2.6 & -2.8 & -2.8 & -2.9 & -3.0 & -3.3 & -3.3 \\
\hline Social security benefits & 14.3 & 15.2 & 15.6 & 15.7 & 16.0 & 16.1 & 16.2 \\
\hline Other current & 3.3 & 3.5 & 3.5 & 3.6 & 3.5 & 3.5 & 3.5 \\
\hline Interest paid & 3.3 & 3.2 & 3.0 & 2.8 & 2.7 & 2.8 & 3.1 \\
\hline Capital & 7.0 & 6.2 & 6.0 & 4.8 & 3.3 & 3.7 & 3.6 \\
\hline Investment & 5.2 & 5.0 & 4.7 & 4.3 & 3.7 & 3.6 & 3.4 \\
\hline Land acquisition & 0.8 & 0.7 & 0.6 & 0.6 & 0.4 & 0.4 & 0.4 \\
\hline Capital transfers & 1.0 & 0.5 & 0.6 & -0.1 & -0.8 & -0.3 & -0.1 \\
\hline Ot which: Bank support & 0.7 & 0.1 & 0.3 & 0.0 & 0.0 & 0.0 & 0.0 \\
\hline Balance & -6.9 & -6.9 & -8.5 & -7.8 & -5.6 & -5.3 & -5.0 \\
\hline Primary balance & -5.4 & -5.5 & -7.0 & -6.3 & -4.3 & -4.1 & -3.4 \\
\hline Excluding social security & -4.5 & -4.2 & -5.6 & -5.6 & -3.9 & -3.0 & -2.3 \\
\hline \multirow[t]{2}{*}{ Structural balance (excluding bank support) } & -5.8 & -5.7 & -6.9 & -6.9 & -4.7 & -5.0 & -5.0 \\
\hline & \multicolumn{7}{|c|}{ (Calendar year) } \\
\hline Total revenue & 29.7 & 30.6 & 29.2 & 28.7 & 28.2 & 29.1 & 29.5 \\
\hline Taxes and fines & 17.4 & 18.0 & 16.5 & 16.0 & 16.0 & 16.6 & 17.0 \\
\hline Social security premiums & 10.0 & 10.4 & 10.6 & 10.9 & 10.5 & 10.6 & 10.8 \\
\hline Property income & 2.0 & 1.9 & 1.8 & 1.5 & 1.5 & 1.6 & 1.5 \\
\hline Total expenditure & 37.4 & 36.9 & 37.3 & 36.8 & 34.4 & 34.7 & 34.9 \\
\hline Current & 29.9 & 30.5 & 31.4 & 31.2 & 30.9 & 31.1 & 31.2 \\
\hline Consumption & 11.5 & 11.7 & 12.0 & 12.0 & 11.8 & 11.7 & 11.6 \\
\hline (less) Depreciation & -2.6 & -2.7 & -2.8 & -2.9 & -3.0 & -3.0 & -3.0 \\
\hline Social security benefits & 14.2 & 14.9 & 15.6 & 15.7 & 15.9 & 16.1 & 16.2 \\
\hline Other current & 3.5 & 3.4 & 3.5 & 3.6 & 3.5 & 3.5 & 3.5 \\
\hline Interest paid & 3.4 & 3.2 & 3.1 & 2.8 & 2.7 & 2.7 & 3.0 \\
\hline Capital & 7.5 & 6.4 & 5.9 & 5.6 & 3.5 & 3.6 & 3.7 \\
\hline Investment & 5.2 & 5.1 & 4.8 & 4.3 & 3.9 & 3.6 & 3.4 \\
\hline Land acquisition & 0.8 & 0.8 & 0.7 & 0.6 & 0.5 & 0.4 & 0.4 \\
\hline Capital transfers & 1.5 & 0.6 & 0.5 & 0.7 & -0.9 & -0.4 & -0.2 \\
\hline Ot which: Bank support & 1.2 & 0.3 & 0.2 & 0.1 & 0.0 & 0.0 & 0.0 \\
\hline Balance & -7.7 & -6.4 & -8.2 & -8.1 & -6.3 & -5.6 & -5.4 \\
\hline Primary balance & -6.2 & -4.9 & -6.7 & -6.7 & -4.9 & -4.4 & -3.9 \\
\hline Excluding social security & -5.5 & -3.9 & -5.5 & -5.9 & -4.6 & -3.5 & -2.8 \\
\hline Structural balance (excluding bank support) & -6.0 & -5.4 & -6.7 & -6.9 & -5.5 & -5.1 & -5.3 \\
\hline \multicolumn{8}{|l|}{ Debt (In percent of GDP, calendar year) } \\
\hline Gross & 142.4 & 151.8 & 161.3 & 167.6 & 178.6 & 181.6 & 181.4 \\
\hline Net & 60.4 & 66.1 & 72.7 & 77.3 & 82.2 & 86.7 & 89.6 \\
\hline \multicolumn{8}{|l|}{ Memorandum items: } \\
\hline Nominal GDP (FY, trillion yen) & 502.9 & 492.6 & 488.8 & 493.6 & 496.1 & 505.3 & 522.2 \\
\hline Nominal GDP (CY, trillion yen) & 501.3 & 496.9 & 489.7 & 490.8 & 496.1 & 502.6 & 517.6 \\
\hline
\end{tabular}

Source: Fund staff estimates.

1/ Estimated from the National Income Accounts data. The fiscal year is April through March. 
Table 3. Japan: External and Financial Indicators, 1998-2006

(In percent of GDP, unless otherwise indicated)

\begin{tabular}{|c|c|c|c|c|c|c|c|c|c|}
\hline & 1998 & 1999 & 2000 & 2001 & 2002 & 2003 & 2004 & 2005 & $\begin{array}{r}2006 \\
\text { Latest }\end{array}$ \\
\hline \multicolumn{10}{|l|}{ External indicators } \\
\hline Real exports of goods and services (percent change) & -2.3 & 1.5 & 12.2 & -6.7 & 7.5 & 9.0 & 13.9 & 7.0 & $\ldots$ \\
\hline Real imports of goods and services (percent change) & -6.7 & 3.6 & 8.5 & 1.0 & 0.8 & 4.0 & 8.5 & 6.3 & $\ldots$ \\
\hline Terms of trade (percent change) & 6.7 & 4.6 & -5.0 & -1.0 & 1.0 & 1.7 & -2.2 & -5.2 & $\ldots$ \\
\hline Current account balance & 3.1 & 2.6 & 2.6 & 2.1 & 2.9 & 3.2 & 3.8 & 3.6 & $\ldots$ \\
\hline Capital and financial account balance & -3.1 & -1.2 & -1.9 & -1.4 & -1.7 & 1.5 & 0.4 & -2.6 & $\ldots$ \\
\hline \multicolumn{10}{|l|}{ Of which: } \\
\hline Inward portfolio investment & 1.4 & 2.9 & 1.0 & 1.5 & -0.5 & 1.9 & 4.3 & 4.0 & $\ldots$ \\
\hline Inward direct investment & 0.1 & 0.3 & 0.2 & 0.2 & 0.2 & 0.1 & 0.2 & 0.1 & $\ldots$ \\
\hline Other investment liabilities (net) & -1.4 & 0.1 & -0.3 & 0.7 & 1.6 & 4.4 & 0.4 & -1.4 & $\ldots$ \\
\hline Total reserves minus gold (US\$ billion) & 214.8 & 286.9 & 354.9 & 395.2 & 461.2 & 663.3 & 833.8 & 834.3 & 848.0 \\
\hline In months of imports of goods and services & 7.4 & 9.1 & 9.6 & 11.7 & 14.0 & 18.1 & 19.1 & 17.0 & $\ldots$ \\
\hline Broad money $(\mathrm{M} 2+\mathrm{CDs})$ to reserves ratio & 2.1 & 1.9 & 1.6 & 1.3 & 1.1 & 0.9 & 0.8 & 0.8 & 0.7 \\
\hline Foreign assets of deposit money banks (US\$ billion) & 833.2 & 682.5 & 787.8 & 768.4 & 724.2 & 689.2 & 795.2 & 961.1 & $\ldots$ \\
\hline Foreign liabilities of deposit money banks (US\$ billion) & 612.5 & 478.8 & 568.7 & 565.5 & 536.7 & 505.0 & 576.3 & 588.4 & $\ldots$ \\
\hline Net international investment position (US\$ billion) & $1,153.6$ & 829.1 & $1,157.9$ & $1,249.1$ & $1,598.5$ & $1,721.9$ & $1,852.8$ & $1,986.3$ & $\ldots$ \\
\hline \multicolumn{10}{|l|}{ Of which: } \\
\hline External loan liabilities & 717.7 & 676.8 & 707.2 & 654.5 & 668.0 & 721.7 & 839.0 & 860.2 & $\ldots$ \\
\hline External public sector debt (gross) $1 /$ & 244.0 & 208.7 & 271.7 & 232.8 & 189.1 & 205.6 & 319.0 & 383.2 & $\ldots$ \\
\hline External loan liabilities to exports ratio & 1.7 & 1.5 & 1.4 & 1.5 & 1.5 & 1.4 & 1.4 & 1.3 & $\ldots$ \\
\hline External interest payments to exports (in percent) $2 /$ & 7.2 & 4.5 & 3.9 & 4.1 & 2.3 & 1.7 & 1.4 & 1.7 & $\ldots$ \\
\hline Nominal effective exchange rate (percent change) & 2.4 & 13.5 & 8.7 & -8.1 & -4.5 & 3.1 & 3.9 & -3.2 & -5.4 \\
\hline \multicolumn{10}{|l|}{ Financial market indicators } \\
\hline General government gross debt & 120.7 & 134.5 & 142.5 & 151.9 & 161.4 & 167.6 & 178.6 & 181.7 & $\ldots$ \\
\hline \multicolumn{10}{|l|}{ Interest rates (percent, end-year) } \\
\hline 3-month Gensaki rate & 0.14 & 0.07 & 0.32 & 0.01 & 0.003 & 0.001 & 0.001 & 0.001 & 0.003 \\
\hline 3-month Gensaki rate, real & -0.45 & 1.15 & 0.72 & 1.21 & 0.31 & 0.41 & -0.20 & 0.10 & 0.00 \\
\hline 3-month interest rate spread vis-à-vis U.S. & -4.28 & -5.16 & -5.51 & -1.71 & -1.19 & -0.89 & -2.20 & -3.89 & -4.51 \\
\hline Stock market index (TOPIX, percent change, end-year) 3/ & -7.5 & 58.4 & -25.5 & -19.6 & -18.3 & 23.8 & 10.2 & 43.5 & 38.1 \\
\hline \multicolumn{10}{|l|}{ Banking sector risk indicators } \\
\hline Total loans to assets (in percent) & 49.9 & 47.3 & 44.3 & 39.6 & 38.2 & 34.6 & 32.6 & 31.0 & $\ldots$ \\
\hline Total loans to deposits (in percent) & 105.1 & 98.9 & 97.8 & 93.4 & 87.3 & 81.9 & 78.8 & 78.4 & $\ldots$ \\
\hline Share of real estate sector in total lending (in percent) & 14.2 & 14.5 & 14.9 & 14.9 & 14.6 & 13.8 & 14.5 & 14.9 & ... \\
\hline \multicolumn{10}{|l|}{ Share of nonperforming loans in total loans } \\
\hline (In percent, end-fiscal year) 4/ & 6.1 & 5.4 & 5.3 & 8.4 & 7.2 & 5.2 & 2.9 & $\ldots$ & $\ldots$ \\
\hline Risk-weighted capital ratio (in percent, end-fiscal year) 4/ & 11.6 & 11.8 & 11.7 & 10.8 & 9.4 & 11.2 & 11.6 & $\ldots$ & $\ldots$ \\
\hline
\end{tabular}

Sources: Global Insight, Nomura Database; IMF, International Financial Statistics; Fitch IBCA; and Fund staff estimates.

1/ Public sector debt securities and other loan liabilities.

2/ Other investment income, debit.

3/ Twelve-month percent change for the latest figure.

4/ Major banks. Capital ratio is on a nonconsolidated basis. 


\section{ANNEX I. JAPAN-STRUCTURAL REFORM AGENDA}

\section{Steady progress has been made in structural reforms but more remains to be} done. Mark-ups and prices remain relatively high (OECD, 2004), while productivityparticularly in sectors such as food and retail - has been low. A recent report by the Ministry of the Economy, Trade and Industry (2006) shows that labor productivity of these sectors is about 40 percent lower in Japan than in the United States. These facts suggest limited competition, resource misallocation, and impediments to factor mobility.

\section{Structural reforms have potentially large payoffs in terms of output and growth.} Static gains could be as large as 8 percent of GDP, and dynamic gains could be in a range of 0.3 to 2.4 percent. With this as backdrop, this annex discusses structural reform priorities and potential benefits in the areas of labor markets, deregulation and product markets, and trade and agriculture.

\begin{tabular}{|c|c|c|c|}
\hline \multicolumn{4}{|c|}{ Estimates of Gains from Structural Reform in GDP Terms } \\
\hline & Bradford & $\begin{array}{c}\text { Economic Planning } \\
\text { Agency }\end{array}$ & OECD \\
\hline \multirow[t]{2}{*}{ Year published } & 2002 & 1994 & 2004 \\
\hline & \multicolumn{3}{|c|}{ (In percent) } \\
\hline Static gain & 2.2 & 8.0 & 5.2 \\
\hline 1-year gain (5-year horizon) & 0.4 & 1.6 & 1.0 \\
\hline Overall gain (5-year horizon) & 2.2 & 8.0 & 5.2 \\
\hline \multirow[t]{2}{*}{ Main reform measure(s) or assumption: } & $\begin{array}{l}\text { Eliminate tariffs } \\
\text { and non-tariff } \\
\text { barriers }\end{array}$ & $\begin{array}{c}\text { General } \\
\text { Deregulation }\end{array}$ & Regulatory reform \\
\hline & $\begin{array}{c}\text { TFP Growth } \\
\text { Reversion } \\
\text { (Prescott-Hayashi) }\end{array}$ & $\begin{array}{l}\text { Japan Center for } \\
\text { Economic Research }\end{array}$ & MITI/Sanwa \\
\hline \multirow[t]{2}{*}{ Year published } & 2002 & 2003 & 2000 \\
\hline & \multicolumn{3}{|c|}{ (In percent) } \\
\hline Dynamic gain & 2.2 & 0.3 & 2.4 \\
\hline 1-year gain (5-year horizon) & 2.2 & 0.3 & 2.4 \\
\hline Overall gain (5-year horizon) & 12.4 & 1.6 & 12.6 \\
\hline Main reform measure(s) or assumption: & $\begin{array}{l}\text { Reversion of TFP } \\
\text { growth to } 1980 \text { 's } \\
\text { rate }\end{array}$ & $\begin{array}{l}\text { Regulatory reform } \\
\text { mainly in public } \\
\text { services }\end{array}$ & $\begin{array}{l}\text { Deregulation and rapid } \\
\text { diffusion of IT }\end{array}$ \\
\hline
\end{tabular}




\section{A. Labor Market}

\section{With the working-age population shrinking, further efforts to boost regular} employment and broaden participation are needed. The historically-high share of parttime workers, while adding labor market flexibility, may limit accumulation of human capital because of short job tenure. In addition, the increase in structural unemployment since the early 1990s points to a possible increase in skill mismatches. Meanwhile, participation rates for women are relatively low, (and are declining for the younger generations), reflecting a lack of family-friendly policies (e.g., affordable good-quality childcare and long working hours), as well as unequal job opportunities and wage discrimination. Priorities could include:

- $\quad$ Establishing more flexible labor hours (including by implementing the Childcare and Family Care Leave Act), as well as providing focused financial support for parents in need of childcare, and encouraging the supply of high-quality childcare; avoiding discrete jumps in social security contributions for families when spouses return to work; and providing job search support through government and private agencies.

- Clarifying conditions for dismissing workers (including whether compensated layoffs are legal).

- $\quad$ Providing appropriate job training to equip young people with career development plans and the necessary skills to achieve them. A review of the system of personal deductions for adult children living with their parents and social security contributions could also strengthen incentive to participate in labor markets.

- $\quad$ Improving the portability of corporate pensions (to enhance labor mobility). In particular, participation in defined contribution plans could be broadened (for example, employees of companies with corporate defined benefit pension plans cannot join these plans), and upper limits on contributions could be raised further.

- $\quad$ Facilitating further development of employment agencies.

Such steps could have significant payoffs. For example, a 1 percentage point rise in the female participation rate would raise output by about $1 / 2$ percentage point. (The female participation ratio is 9 percentage points higher in the United States and United Kingdom than in Japan.)

\section{B. Deregulation and Product Markets}

4. High mark-ups and prices reflect weak competition and barriers to entry, as well as inefficiencies in retail distribution and network industries (especially energy, as shown in OECD $(2004,2005))$. In addition, inward FDI is low owing to regulatory factors 
and limited market contestability, hampering international knowledge transfer. However, steps have recently been taken to promote competition: the new Antimonopoly Act enhances powers and resources for the Fair Trade Commission, with stiffer surcharges and penalties for anticompetitive behavior.

5. Retail distribution: Certain trading practices imposed by producers, such as standard prices and rebates, may restrict competition. In this connection, regular assessments of the effectiveness of competition policy by the Fair Trade Commission (through ex-post indicators such as margins) would be desirable. As the retail sector accounts for over 10 percent of aggregate output, potential gains of comprehensive reforms are largeestimated by the OECD (2004) as exceeding 2 percent of GDP.

6. Network industries: Deregulation has begun, but network industries remain less open to competition than in many countries, and need appropriate regulatory frameworks.

(a) Post and Telecommunications: thanks to past deregulation, the price of internet access and cellular phone interconnection rates have fallen to among the lowest in the OECD. Key next steps could include: (i) establishing an independent telecoms regulator (as in most OECD countries), to separate the government's roles as shareholder and regulator ${ }^{1}$;

(ii) leveling the playing field by removing ownership restrictions in telecoms; and

(iii) enhancing competition in the postal sector, for example by abolishing strict service obligations for general correspondence delivery business operators. ${ }^{2}$ The OECD (2004) estimates the potential payoff from reforms in these sectors to be about $1 / 2$ percent of GDP.

(b) Energy: retail choice of electricity has been expanded to 63 percent of the market in electricity as of 2005. In natural gas, following passage of the amended Gas Industry Law in 2005, retail choice is expected to grow over time to 59 percent of the market. However, prices remain high, as shown in $\operatorname{OECD}(2004,2005)$. Priorities could include: (i) setting up effective, independent sectoral regulators; and (ii) enhancing incentives for infrastructure investment, including by bringing together networks in electricity into a separate firm. OECD (2004) estimates that the economic gains from achieving fully competitive energy markets would exceed $1 / 2$ percent of GDP.

7. Health Services: Priorities in this sector include opening up the medical sector to commercial providers. For example, by allowing a broader scope for the operation of medical

\footnotetext{
${ }^{1}$ In Japan, different ministries act as shareholder and regulator. Nevertheless, the OECD (2005) suggests that there may be gains from establishing independent sectoral regulators.

${ }^{2}$ There is free entry to the general correspondence delivery business and parcel delivery, but because new entrants into the general correspondence delivery business are subject to some of the same universal service obligations as the incumbent, free entry in that segment exists only in principle.
} 
joint stock companies (JSCs), and rolling out medical JSCs nation-wide. Other priorities include better information disclosure, improving the functioning of the insurance system, and reviewing drug prices. Cabinet Office studies estimate that private enterprises in the fields of medical care, home nursing, and daycare centers are more efficient than their public sector counterparts by margins of 11-38 percent. If private participation in healthcare could increase overall efficiency in the sector by 10-20 percent, with that sector accounting for about 8 percent of expenditure (and that share set to rise), potential benefits could be $3 / 4-1 \frac{1}{2}$ percent of GDP or higher.

8. Inward FDI. FDI into Japan has picked up since the late 1990s but remains low, with the stock relative to GDP less than one-tenth the average in other G-7 countries. This may partly reflect limitations on inward ("out-in") M\&A, which is the main vehicle for inward FDI in developed countries. In particular, foreign firms have been unable to use their stock in "triangular" mergers to acquire Japanese companies. Under the new Corporate Code, triangular mergers will be allowed from May 2007. However, the new Code also increases the range

\begin{tabular}{|lcr|}
\hline \multicolumn{3}{|c|}{$\begin{array}{c}\text { Inward FDI Stock (Liabilities) } \\
\text { (In percent of GDP) }\end{array}$} \\
\hline Country & 1998 & 2004 \\
\hline Japan & 0.7 & 2.1 \\
United States & 24.9 & 22.9 \\
United Kingdom & 24.9 & 34.8 \\
Germany & 11.6 & 24.7 \\
France & 37.3 & 45.8 \\
Italy & 8.7 & 13.2 \\
Canada & 23.2 & 30.6 \\
\hline Source: IMF International Financial Statistics. \\
\hline
\end{tabular}
of possible takeover defenses for Japanese firms, while leaving unclear key issues surrounding the use of foreign shares in M\&A. Priorities to raise inward FDI could include:

- Giving out-in M\&A the same tax deferrals as in-in M\&A;

- Ensuring that foreign shares are effectively usable in M\&A (if normal foreign listed shares are at some point included under the definition of shares with "limited transferability", this would effectively preclude their use of triangular mergers);

- Allowing greater foreign participation in sheltered sectors (such as health care).

9. Murakami and Fukao (2006) find that target firms of out-in M\&A tend to become more productive and thus a pickup in overall out-in M\&A might be expected to boost overall productivity. Ito and Fukao (2003) estimate that if Japan's inward FDI stock (relative to GDP) moved towards the average OECD level, then overall benefits could be around $1 \frac{1}{2}$ percent of GDP.

\section{Agriculture and Trade}

10. High protection in agriculture boosts domestic food prices while stifling sectoral productivity. The recent move from price toward direct support in agriculture has begun to address this problem, but would achieve maximum benefits if taken further, particularly with 
the liberalization of trade in agricultural products and reductions in the high level of overall support to farmers.

- The move to allow nation-wide entry of JSCs in agriculture could be supported by reforms of agricultural cooperatives, which are major players in agricultural business, (e.g., by promoting more efficient and transparent management, and enhanced disclosure on cost-revenue structure and subsidies); steps could also be taken to promote economies of scale in land use.

- On trade, ambition would be desirable in the Doha Round, and in the commitment to offering duty and quota free access on at least 97 percent of tariff lines for products from LDCs under the WTO Hong Kong Ministerial in December 2005 (particularly in areas such as agriculture that could spur productivity gains). Preferential trade agreements, known as "Economic Partnership Agreements" in Japan, could emphasize complementary liberalization on a most favored nation (MFN) basis (to mitigate trade diversion) and be implemented with transparent, consistent, and liberal rules of origin.

\section{The potential benefits of complementary agricultural and trade reforms are} sizable (see Japan: Selected Issues, 2005). Bradford (2003) estimates the gains from the elimination of tariffs and non-tariff barriers to be 2.2 percent of GDP. Tokarick (2005) estimates that a full multilateral agricultural policy reform would yield a welfare gain for Japan of $1 / 2$ percent of GDP. Francois and others (2005), suggest that agricultural policy reform that results in a flow of the factors of production out of agriculture and into sectors such as manufacturing could more than double the estimated welfare benefits of agricultural reforms. 


\section{References}

Bradford, Scott, 2003, "Paying the Price: Final Goods Protection in OECD Countries," The Review of Economics and Statistics, February 2003.

Francois, Joseph, Hans van Meijl, and Frank van Tongeren, 2005, "Gauging the WTO Negotiation's Potential Gains," Economic Policy, April.

Fukao, Kyoji, and Ito, Keiko, 2003, "Foreign Direct Investment in Japan: Empirical Analysis Based on Establishment and Enterprise Census for 1996," Japan's Economic Recovery (R. M. Stern ed.) Edward Elgar, pp. 163-219.

Fukao, Kyoji, and Murakami, Yukako, 2006, Inward Foreign Direct Investments and Productivity Growth in Japan, Hi-Stat DP Series, No.143, the Institute of Economic Research, Hitotsubashi University.

Hayashi, Fumio, and Prescott, Edward, 2002, "The 1990's in Japan: A Lost Decade," Review of Economic Dynamics, Vol. 5 (Special Issue, January)

Imai, Yutaka, and Kawagoe, Masaaki, 2000, "Business Startups in Japan: Problems and Policies," Oxford Review of Economic Policy, Vol. 16, No. 2.

Japan Center for Economic Research, 2003, "Regulatory Reform and Demand Creation," December 2003.

McDonald, Brad, 2005, "Agricultural Policies in Japan: Domestic and Spillover Effects" Japan: Selected Issues, IMF Country Report No. 05/272, August 2005.

Ministry of Economy, Trade, and Industry, 2003 "Naigai kakaku chousa houkoku sho," July 2003.

— 2006 “New Economic Growth Strategy, Interim Report,” March 2006.

Ministry of International Trade and Industry, Sanwa Research Institute, 2000, "Keizai kouzou kaikaku no kouka shisan ni tsuite," December 2000.

Ministry of Public Management, Home Affairs, Posts and Telecommunications, 2002, "Denki tsushin sabisu ni kakaru naigai kakakusa ni kansuru chousa (Survey on Price Variances between Domestic and Overseas Telecommunications Services)." 
Organization for Economic Cooperation and Development, 2004, OECD Economic Surveys: Japan, Volume 2003/18.

— 2005, OECD Economic Surveys: Japan, Volume 2005/3.

Shimpo, Seiji, and Nishizaki, Fumihara, 1997, "Measuring the Effects of Regulatory Reform in Japan: A Review," Economic Planning Agency.

Tokarick, Stephen, 2005, "Who Bears the Cost of Agricultural Support in OECD Countries?" World Economy.

Walker, Christopher, 2004, "Structural Reforms and Productivity Growth" Japan: Selected Issues, IMF Country Report No. 04/247, August 2004. 
Japan: Public Sector Debt Sustainability Framework, 2000-2011

(In percent of GDP, unless otherwise indicated; calendar year basis)

\begin{tabular}{|c|c|c|c|c|c|c|c|c|c|c|c|c|c|c|}
\hline & \multicolumn{5}{|c|}{ Actual } & & & \multirow[b]{2}{*}{2005} & \multirow[b]{2}{*}{2006} & \multirow[b]{2}{*}{2007} & \multirow[b]{2}{*}{2008} & \multirow[b]{2}{*}{2009} & \multirow[b]{2}{*}{2010} & \multirow[b]{2}{*}{201} \\
\hline & 2000 & 2001 & 2002 & 2003 & 2004 & & & & & & & & & \\
\hline $\begin{array}{l}\text { Net general government debt } \\
\text { Of which: Foreign currency-denominated }\end{array}$ & $\begin{array}{r}60.4 \\
0.0\end{array}$ & $\begin{array}{r}66.1 \\
0.0\end{array}$ & $\begin{array}{r}72.7 \\
0.0\end{array}$ & $\begin{array}{r}77.3 \\
0.0\end{array}$ & $\begin{array}{r}82.2 \\
0.0\end{array}$ & & & $\begin{array}{r}86.7 \\
0.0\end{array}$ & $\begin{array}{r}89.6 \\
0.0\end{array}$ & $\begin{array}{r}92.5 \\
0.0\end{array}$ & $\begin{array}{r}95.0 \\
0.0\end{array}$ & $\begin{array}{r}96.9 \\
0.0\end{array}$ & $\begin{array}{r}98.5 \\
0.0\end{array}$ & $\begin{array}{r}99.9 \\
0.0\end{array}$ \\
\hline Change in public sector debt & 6.3 & 5.7 & 6.6 & 4.5 & 4.9 & & & 4.5 & 2.8 & 3.0 & 2.5 & 1.9 & 1.6 & 1.4 \\
\hline Identified debt-creating flows & 7.1 & 6.9 & 9.1 & 8.0 & 5.4 & & & 4.5 & 2.9 & 3.0 & 2.5 & 1.9 & 1.6 & 1.4 \\
\hline Primary deficit & 6.2 & 4.9 & 6.7 & 6.7 & 4.9 & & & 4.4 & 3.9 & 3.4 & 2.8 & 2.2 & 1.6 & 1.3 \\
\hline Revenue and grants & 29.7 & 30.6 & 29.2 & 28.7 & 28.2 & & & 29.1 & 29.5 & 30.2 & 30.9 & 31.5 & 32.1 & 32.7 \\
\hline Primary (noninterest) expenditure & 35.9 & 35.5 & 35.9 & 35.4 & 33.1 & & & 33.5 & 33.4 & 33.6 & 33.7 & 33.7 & 33.8 & 34.1 \\
\hline Contribution from interest rate/growth differential $2 /$ & 0.9 & 2.0 & 2.4 & 1.3 & 0.5 & & & 0.1 & -1.0 & -0.4 & -0.3 & -0.3 & -0.1 & 0.1 \\
\hline Of which: Contribution from real interest rate & 2.4 & 2.2 & 2.5 & 2.6 & 2.2 & & & 2.2 & 1.5 & 1.5 & 1.4 & 1.4 & 1.6 & 1.7 \\
\hline Of which: Contribution from real GDP growth & -1.6 & -0.2 & -0.1 & -1.3 & -1.7 & & & -2.1 & -2.5 & -1.9 & -1.8 & -1.7 & -1.6 & -1.6 \\
\hline Other identified debt-creating flows & 0.0 & 0.0 & 0.0 & 0.0 & 0.0 & & & 0.0 & 0.0 & 0.0 & 0.0 & 0.0 & 0.0 & 0.0 \\
\hline Privatization receipts (negative) & 0.0 & 0.0 & 0.0 & 0.0 & 0.0 & & & 0.0 & 0.0 & 0.0 & 0.0 & 0.0 & 0.0 & 0.0 \\
\hline Recognition of implicit or contingent liabilities & 0.0 & 0.0 & 0.0 & 0.0 & 0.0 & & & 0.0 & 0.0 & 0.0 & 0.0 & 0.0 & 0.0 & 0.0 \\
\hline Other (specify, e.g., bank recapitalization) & 0.0 & 0.0 & 0.0 & 0.0 & 0.0 & & & 0.0 & 0.0 & 0.0 & 0.0 & 0.0 & 0.0 & 0.0 \\
\hline Residual, including asset changes & -0.7 & -1.2 & -2.5 & -3.5 & -0.5 & & & 0.0 & 0.0 & 0.0 & 0.0 & 0.0 & 0.0 & 0.0 \\
\hline Net general government debt-to-revenue ratio $1 /$ & 203.0 & 216.2 & 249.3 & 269.1 & 291.8 & & & 298.4 & 303.5 & 306.6 & 307.7 & 307.7 & 306.3 & 305.2 \\
\hline Gross financing need $3 /$ & 26.2 & 27.1 & 31.0 & 32.7 & 32.2 & & & 33.1 & 33.8 & 34.7 & 35.3 & 35.7 & 36.1 & 36.5 \\
\hline Key macroeconomic and fiscal assumptions & & & & & & $\begin{array}{l}10 \text {-Year } \\
\text { Historical } \\
\text { Average }\end{array}$ & $\begin{array}{l}\text { 10-Year } \\
\text { Standard } \\
\text { Deviation }\end{array}$ & & & & & & & \\
\hline Real GDP growth (in percent) & 2.9 & 0.4 & 0.1 & 1.8 & $2.3^{-}$ & 1.1 & 1.5 & 2.6 & 2.9 & 2.1 & 1.9 & 1.9 & 1.8 & 1.7 \\
\hline Average nominal interest rate on public debt (in percent) $4 /$ & 2.8 & 2.3 & 2.2 & 2.0 & 1.7 & 3.5 & 1.6 & 1.4 & 1.8 & 2.0 & 2.4 & 2.8 & 3.0 & 3.3 \\
\hline Average real interest rate (nominal rate minus change in GDP deflator, in percent) & 4.5 & 3.6 & 3.8 & 3.6 & 2.9 & 4.4 & 1.2 & 2.7 & 1.7 & 1.7 & 1.6 & 1.6 & 1.7 & 1.8 \\
\hline Inflation rate (GDP deflator, in percent) & -1.7 & -1.3 & -1.6 & -1.6 & -1.2 & -0.9 & 0.7 & -1.3 & 0.0 & 0.4 & 0.8 & 1.2 & 1.3 & 1.5 \\
\hline Growth of real primary spending (deflated by GDP deflator, in percent) & 4.2 & -0.8 & 1.1 & 0.5 & -4.3 & 1.5 & 3.2 & 3.8 & 2.6 & 2.7 & 2.2 & 1.9 & 2.1 & 2.5 \\
\hline Primary deficit & 6.2 & 4.9 & 6.7 & 6.7 & 4.9 & 5.0 & 1.4 & 4.4 & 3.9 & 3.4 & 2.8 & 2.2 & 1.6 & 1.3 \\
\hline \multicolumn{15}{|l|}{ A. Alternative scenarios } \\
\hline A1. Key variables are at their historical averages in 2005-11 5/ & & & & & & & & 86.7 & 94.5 & 102.5 & 110.8 & 119.4 & 128.2 & 137.4 \\
\hline \multicolumn{15}{|l|}{ B. Bound tests } \\
\hline B1. Real interest rate is at historical average plus two standard deviations in 2006 a & & & & & & & & 86.7 & 93.9 & 101.5 & 104.0 & 105.8 & 107.4 & 108.8 \\
\hline B2. Real GDP growth is at historical average minus two standard deviations in 2000 & 2007 & & & & & & & 86.7 & 95.4 & 105.2 & 110.7 & 115.6 & 120.2 & 124.8 \\
\hline B3. Primary balance is at historical average minus two standard deviations in 2006 & 2007 & & & & & & & 86.7 & 93.5 & 100.8 & 103.3 & 105.1 & 106.7 & 108.1 \\
\hline B4. Combination of $1-3$ using one standard deviation shocks & & & & & & & & 86.7 & 93.7 & 105.7 & 110.1 & 113.9 & 117.4 & 120.9 \\
\hline
\end{tabular}

Sources: Data from the Japanese authorities; and Fund staff estimates.

1/ Derived as $[(r-p(1+g)-g] /(1+g+p+g p))$ times previous period debt ratio, with $r=$ interest rate; $p=$ growth rate of GDP deflator; $g=$ real GDP growth rate. enth contributions are derived from the numerator in footnote $1 /$

$3 /$ Defined as public sector deficit, plus amortization of medium and long-term public sector debt, plus short-term debt at end of previous period.

4/ Derived as nominal interest expenditure divided by previous period debt stock.

5/ The key variables include real GDP growth; real interest rate; and primary balance in percent of GDP. 
ANNEX II. JAPAN-DEBT SUSTAINABILITY ANALYSIS - CONCLUDED

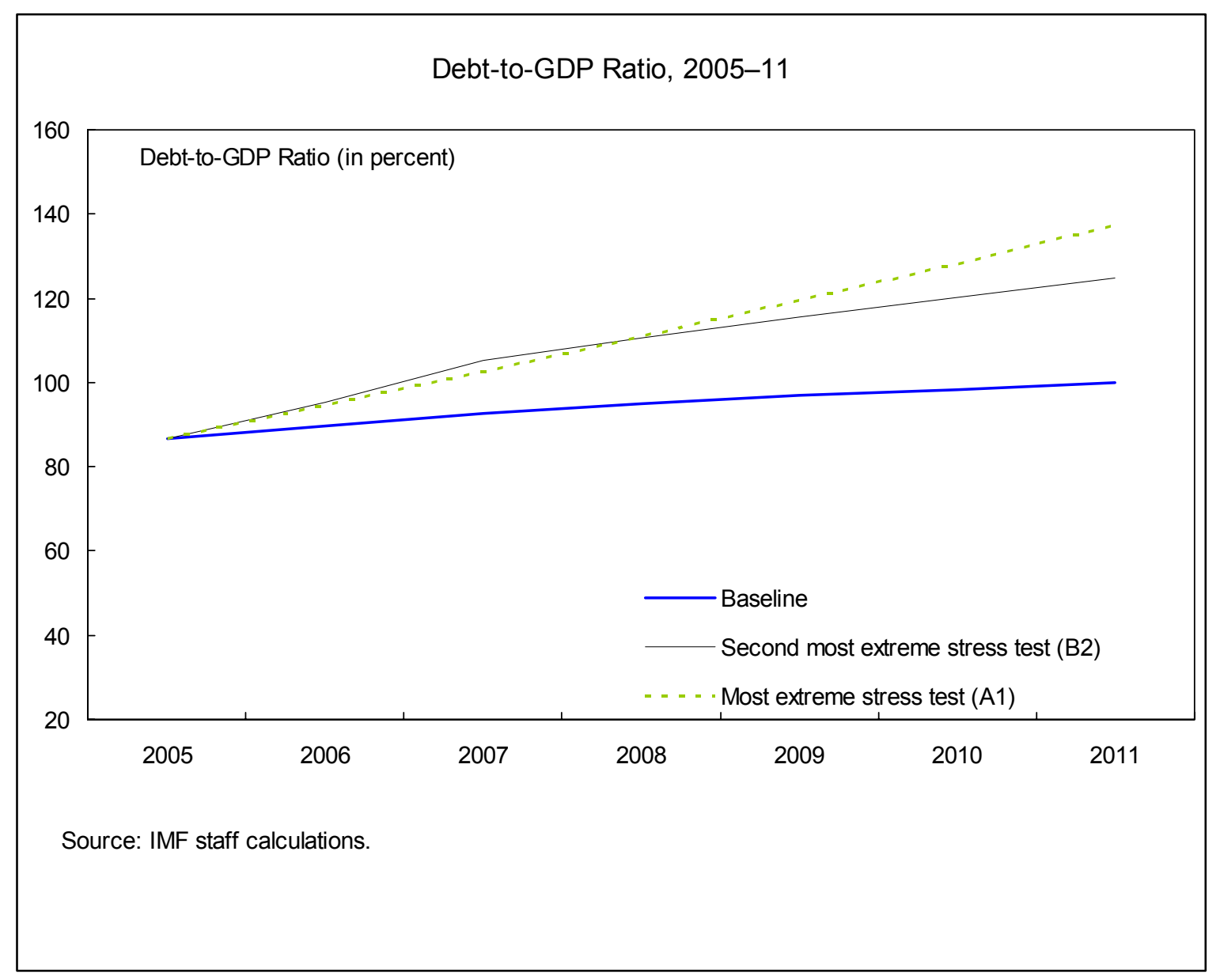

CInternational Monetary Fund. Not for Redistribution 


\section{ANNEX III. JAPAN-STATISTICAL ISSUES}

Statistical Issues: Economic and financial data provided to the Fund are considered adequate for surveillance purposes. Japan subscribes to the Special Data Dissemination Standard (SDDS) and meets the SDDS specifications for the coverage, periodicity, and timeliness of data. The Japanese authorities hosted a data module mission for a Report on the Observance of Standards and Codes (data ROSC) in September 12-28, 2005. The Report on Observance of Standards and Codes Data Module, Response by the Authorities, and Detailed Assessments Using the Data Quality Assessment Framework (DQAF) were published March 17, 2006 and are available http://www.imf.org/external/pubs/ft/scr/2006/cr06115.pdf.

Japan: Table of Common Indicators Required for Surveillance (As of June 27, 2006)

\begin{tabular}{|c|c|c|c|c|c|}
\hline & $\begin{array}{c}\text { Date of } \\
\text { Latest } \\
\text { Observation }\end{array}$ & $\begin{array}{l}\text { Date } \\
\text { Received }\end{array}$ & $\begin{array}{c}\text { Frequency } \\
\text { of } \\
\text { Data }^{5}\end{array}$ & $\begin{array}{c}\text { Frequency } \\
\text { of } \\
\text { Reporting }^{5}\end{array}$ & $\begin{array}{c}\text { Frequency } \\
\text { of } \\
\text { Publication }^{5}\end{array}$ \\
\hline Exchange Rates & $6 / 27 / 06$ & $6 / 27 / 06$ & $\mathrm{D}$ & $\mathrm{D}$ & $\mathrm{D}$ \\
\hline $\begin{array}{l}\text { International Reserve Assets and Reserve Liabilities of } \\
\text { the Monetary Authorities }{ }^{1}\end{array}$ & $4 / 06$ & $6 / 06$ & M & M & M \\
\hline Reserve/Base Money & $4 / 06$ & $6 / 06$ & M & M & M \\
\hline Broad Money & $4 / 06$ & $6 / 06$ & M & M & M \\
\hline Central Bank Balance Sheet & $6 / 20 / 06$ & $6 / 22 / 06$ & $\begin{array}{r}\text { Every } 10 \\
\text { days }\end{array}$ & $\begin{array}{r}\text { Every } 10 \\
\text { days }\end{array}$ & $\begin{array}{r}\text { Every } 10 \\
\text { days }\end{array}$ \\
\hline Consolidated Balance Sheet of the Banking System & $4 / 06$ & $5 / 06$ & M & M & M \\
\hline Interest Rates ${ }^{2}$ & $6 / 27 / 06$ & $6 / 27 / 06$ & $\mathrm{D}$ & $\mathrm{D}$ & $\mathrm{D}$ \\
\hline Consumer Price Index & $4 / 06$ & $6 / 06$ & M & M & M \\
\hline $\begin{array}{l}\text { Revenue, Expenditure, Balance and Composition of } \\
\text { Financing }^{1}-\text { General Government }\end{array}$ & 2004 & $4 / 06$ & $A$ & $A$ & $A$ \\
\hline $\begin{array}{l}\text { Revenue, Expenditure, Balance and Composition of } \\
\text { Financing }{ }^{1}-\text { Central Government }\end{array}$ & 2005 & $12 / 05$ & $A$ & $A$ & $A$ \\
\hline $\begin{array}{l}\text { Stocks of Central Government and Central } \\
\text { Government-Guaranteed Debt }{ }^{4}\end{array}$ & $3 / 06$ & $5 / 06$ & $Q$ & $Q$ & $Q$ \\
\hline External Current Account Balance & $4 / 06$ & $6 / 06$ & M & M & M \\
\hline Exports and Imports of Goods and Services & $4 / 06$ & $6 / 06$ & M & M & M \\
\hline GDP/GNP & 2006 Q1 & $6 / 06$ & Q & Q & Q \\
\hline Gross External Debt & $3 / 06$ & $5 / 06$ & Q & Q & Q \\
\hline
\end{tabular}


ANNEX IV. JAPAN-Fund RELATIONS

(As of May 31, 2006)

I. Membership Status: Joined 8/13/52; Article VIII

II. General Resources Account:

SDR Million

Quota

$13,312.80$

$\%$ Quota

Fund holdings of currency

$11,844.73$

100.00

Reserve position in Fund

$1,469.23$

88.97

11.04

III. SDR Department:

SDR Million

\% Allocation

Net cumulative allocation

891.69

100.00

Holdings

$1,827.47$

204.94

IV. Outstanding Purchases and Loans:

None

V. Financial Arrangements:

None

VI. Projected Obligations to Fund:

None

\section{Exchange Rate Arrangement:}

Japan maintains a floating exchange rate regime. The exchange system is free of restrictions on the making of payments and transfers for current international transactions, with the exceptions of restrictions maintained against (1) the Taliban, Al-Qaeda, the former Iraqi regime, and others, pursuant to UN Security Council Resolutions and (2) Former Yugoslavia's President Milosevic and affiliated persons. These restrictions were notified to the Fund in accordance with Executive Board Decision No. 144-(52/51).

\section{Article IV Consultation:}

The 2005 Article IV consultation discussions were held during May 16-26 2005; the Executive Board discussed the Staff Report (IMF Country Report No. 05/273) and concluded the consultation on July 29, 2005. Executive Directors welcomed the further signs of progress in resolving the legacies of the bubble years in Japan. Directors noted that the financial system had been stabilized, the corporate sector made more resilient, labor markets had become more dynamic, and fiscal consolidation is under way. As a result, the economy appeared better positioned to sustain an expansion. Against this background, Directors considered that policies should build on the existing reform program in order to resolve remaining weaknesses promptly, boost Japan's economic potential, and thereby sustain the expansion over the longer term. The staff report, staff supplement, selected issues paper, and PIN were all published. 
INTERNATIONAL MONETARY FUND

JAPAN

\section{Staff Report for the 2006 Article IV Consultation}

\section{Supplementary Information}

Prepared by the Asia and Pacific Department

Approved by Daniel Citrin and Carlo Cottarelli

July 18,2006

1. This supplement provides an update of economic and policy developments since the release of the staff report (6/30/06). The thrust of the staff appraisal remains unchanged.

2. Data released in the past three weeks confirm a solid economic expansion.

- $\quad$ The Bank of Japan's June Tankan short-term corporate survey shows strong business sentiment and positive outlooks for sales, profits, and capital spending.

- $\quad$ Bank lending is growing at its fastest rate in over a decade-just under $23 / 4$ percent $(\mathrm{y} / \mathrm{y})$ in June (after adjustments for write-offs and other special factors).

- $\quad$ Labor markets continue to improve. The unemployment rate fell to 4 percent in May, employment rose $1 / 4$ percent $(y / y)$, and summer bonuses hit a record high.

- $\quad$ The core CPI (which excludes fresh food) rose 0.6 percent (y/y) in May, marking the seventh month of positive inflation.

- Notwithstanding further moderation in import growth, the trade surplus continues to shrink. For the first five months of 2006, the surplus was US $\$ 27.5$ billion (1 $1 / 2$ percent of GDP), down from US $\$ 40.5$ billion (or just over 2 percent of GDP) in the same period last year.

The staff will review its growth projections following the release of second quarter GDP data in August. At this stage, recent developments are consistent with our latest WEO forecasts (shown in the staff report).

3. On July 14, the Bank of Japan increased its overnight policy rate to 25 basis points, ending over five years of effectively zero rates. In announcing the policy shift, the 
Bank of Japan noted that "an accommodative monetary environment ensuing from very low interest rates will probably be maintained for some time." The move was widely anticipated in financial markets. Staff considers that the modest removal of accommodation is an appropriate step toward a more neutral monetary stance and is consistent with sustained noninflationary growth.

\section{On July 7, the Cabinet issued its Basic Policies 2006, which contains-in broad} outline - a revised fiscal plan. In this document (not yet in official translation), the authorities reiterate their intention to achieve a primary balance excluding social security in 2011 and their goal of starting to reduce the debt ratio by the mid-2010s. Basic Policies offers a "Roadmap for Income and Expenditure Reform" to balance the primary account excluding social security. This calls for savings of $¥ 16.5$ trillion (about $23 / 4$ percent of GDP). The report suggests that the bulk of the adjustment (up to $¥ 14.3$ trillion) would be borne by expenditure measures. Savings would be achieved by steps such as reducing the government payroll, social welfare outlays, and public works spending. Additional revenue will also be needed (up to $¥ 5$ trillion), but no specific measures have been identified, pending the results of a re-evaluation of Japan's tax system. In the staff's view, the envisaged fiscal adjustment should be achievable, particularly in light of the favorable conjuncture, but it could be more ambitious, as discussed in the staff report.

5. Basic Policies 2006 also outlines the reform program for the medium term. The authorities provide a comprehensive description of initiatives underway and areas for further action. However, there is no explicit prioritization in the strategy, and a clearer focus on those reforms that promise the largest payoffs (along the lines of the staff report) would have been helpful to speed up implementation, going forward.

\section{In the last three weeks, Japan's financial markets have by and large reflected} geopolitical events. North Korea's July 4 missile tests sparked a short-lived sell-off of equities. More recently, oil price spikes related to conflict in the Middle East have weighed on the stock market. On balance, however, the turbulence has so far been limited, and asset prices (including the exchange rate) are only modestly below end-June levels. 
Public Information Notice (PIN) No. 06/81

FOR IMMEDIATE RELEASE

July 28, 2006
International Monetary Fund

$70019^{\text {th }}$ Street, NW

Washington, D. C. 20431 USA

\section{IMF Executive Board Concludes 2006 Article IV Consultation with Japan}

On July 21, 2006, the Executive Board of the International Monetary Fund (IMF) concluded the Article IV consultation with Japan. ${ }^{1}$

\section{Background}

Deflation has ended and the economy is on a strong recovery path. GDP growth in 2005 was around $23 / 4$ percent, led mainly by private consumption and investment. Labor markets are tightening and the unemployment rate remains around an eight-year low. The pace of activity in the first quarter of 2006 continued briskly at about 3 percent (seasonally adjusted at an annual rate), following an exceptionally strong fourth quarter. Core inflation (CPI excluding fresh food) has been clearly positive since November 2005 (year-on-year core inflation was 0.6 percent in May). The GDP deflator continues to decline, but the deflator for domestic demand is rising marginally. However, other measures confirm the upward trend in price pressures; land prices in urban areas have halted a fifteen year slide and are beginning to rebound.

The yen, in real effective terms, is currently about $63 / 4$ percent weaker than a year ago. After depreciating nearly 15 percent in 2005 against the U.S. dollar as interest rate differentials widened, the yen has appreciated modestly this year (mainly against the dollar), reflecting the markets' reassessment of the likely pace of monetary tightening in major economies. No intervention has occurred since March 2004.

\footnotetext{
${ }^{1}$ Under Article IV of the IMF's Articles of Agreement, the IMF holds bilateral discussions with members, usually every year. A staff team visits the country, collects economic and financial information, and discusses with officials the country's economic developments and policies. On return to headquarters, the staff prepares a report, which forms the basis for discussion by the Executive Board. At the conclusion of the discussion, the Managing Director, as Chairman of the Board, summarizes the views of Executive Directors, and this summary is transmitted to the country's authorities.
}

Washington, D.C. 20431 • Telephone 202-623-7100 • Fax 202-623-6772 • www.imf.org 
The external surplus is narrowing. The trade balance fell in 2005 by $3 / 4$ percent of GDP, in spite of yen depreciation. The current account declined more modestly as factor income surged. Heavy purchases of foreign bonds and repatriation of funds by foreign banks strengthened the financial account, notwithstanding record foreign purchases of domestic equities.

The financial and corporate sectors are in their best shape in over a decade. Under tougher regulation, major banks' nonperforming loans fell to below 2 percent of loans in March 2006. Progress at regional banks has been more uneven. Intense corporate restructuring has buoyed profits to record highs and unlocked productivity gains. With credit supply constraints eased and loan demand revived, bank lending (adjusted for provisions and write-offs) has been trending up since mid-2005, after eight years of contraction.

Monetary policy remains appropriately accommodative. On March 9, the Bank of Japan shifted its strategy from targeting banks' excess reserves (quantitative easing) to targeting the overnight interest rate. The exit from quantitative easing was smooth, with limited volatility in short-term interest rates and private money market activity picking up.

Fiscal consolidation is ahead of the authorities' schedule, but imbalances remain large, with net general government debt about 90 percent of GDP, among the highest in advanced countries. In FY2005, the general government primary deficit excluding social security is estimated to have narrowed by 1 percent of GDP to around 3 percent of GDP. The FY2006 budget, which rolls back past income tax cuts and curbs some discretionary spending, envisages a further fall of some $1 / 2$ percent of GDP.

The near-term macroeconomic outlook is favorable. GDP growth is projected at nearly 3 percent in 2006 and slightly above 2 percent in 2007. CPI inflation will pick up slowly as capacity utilization rises. Risks are balanced, with downside risks mostly external (volatile oil prices, rising long-term interest rates, or a sharp global slowdown). Low inflation raises the possibility of renewed deflation, particularly if a disorderly unwinding of global imbalances occurs. On the upside, private consumption and investment could show further strength.

For the medium term, growth is anticipated to slow to potential, estimated at 1.7 percent, and the current account to narrow. Potential growth could be higher with stepped-up reforms, a recovery in R\&D and greater business restructuring. Faster productivity growth in a broad range of sectors would also decrease the current account surplus over time, countering the effects of fiscal consolidation.

\section{Executive Board Assessment}

Directors welcomed the continued strong forward momentum in Japan's expansion.

Remaining fragilities in the corporate and financial sector have been largely dealt with, and improvements in labor markets and disposable incomes have strengthened the underpinnings for durable growth driven by domestic demand, with an associated decline in the trade surplus. Directors welcomed the end of deflation as measured by several indices-a watershed for 
Japan. In this connection, they underscored that consumer prices are likely to continue rising and that the risk of a deflationary relapse has receded.

Directors noted, however, that-notwithstanding the prospect of above-potential growth for the near term-major policy challenges remain. They stressed that adopting an appropriate postdeflation monetary framework, undertaking a well-designed fiscal consolidation, and boosting productivity through structural reforms are complementary elements of a strategy for sustained non-inflationary growth. Directors thus urged the authorities to take advantage of the favorable conjuncture to make further progress on all these fronts.

Directors welcomed the smooth transition out of quantitative easing and a return to more normal monetary operations. They commended the Bank of Japan for skillfully managing the policy shift while avoiding undue volatility in financial markets. Directors agreed that, in the near term, the policy stance should remain accommodative-allowing inflation expectations to take a firmer hold and drift up.

Directors agreed that the Bank of Japan's monetary framework is well suited to the postdeflation environment and welcomed the improvement in transparency. They acknowledged that the framework also allows appropriate flexibility for the Bank of Japan to respond to a range of short- and long-term risks to price stability.

Directors suggested that further steps to elaborate various aspects of the new monetary framework could help guide market expectations and may bolster policy credibility. In particular, the clarification of the risks associated with near-zero inflation would help markets to form appropriate expectations about the conduct of policy, including with regard to the zero floor on the "understanding of price stability." Most Directors recommended introducing a higher floor over time, to signal the desirability of a buffer against deflationary shocks. A few Directors, however, noted that periodic reviews of the "understanding of price stability" could weaken the establishment of an anchor for inflation expectations.

Directors noted that the authorities' exchange rate policy remains grounded in the belief that the exchange rate should reflect economic fundamentals. They supported the policy of a market-determined exchange rate, and agreed that official foreign exchange intervention should be limited to counter disorderly movements in the external value of the yen. In that connection, several Directors noted the economy's ability to handle a stronger currency in view of its favorable outlook and improved underpinnings.

Directors welcomed the progress made in fiscal consolidation and noted that recent deficit reductions have not held back the expansion. They observed that the long cyclical upswing has contributed to revenue buoyancy and has made it easier to restrain spending. For the current fiscal year, they encouraged the authorities to save any tax windfall and avoid expansionary measures in the supplementary budget.

Looking forward, Directors observed that fiscal policy faces significant challenges if the public finances are to gain a sounder footing. They welcomed the authorities' commitment to medium-term fiscal consolidation and the recent proposals for achieving it. However, most 
Directors thought that, given the strength of the expansion, a somewhat more front-loaded and ambitious adjustment than envisioned by the authorities would be appropriate. Such an adjustment would stabilize the debt ratio, buy insurance against unanticipated fiscal or economic shocks, and bolster the credibility of the authorities' plan. Some Directors argued, however, that fiscal consolidation needs to be implemented as planned to minimize the risk of weakening the expansion as the global monetary tightening cycle advances.

Directors emphasized that further financial sector reforms will accelerate development of securities markets, improve the financial system's resilience to shocks, and help to sustain non-inflationary growth over the medium term. They welcomed the steps under way to reduce the government's role in intermediation, streamline and clarify securities regulation, and bolster financial risk management, which will help safeguard the stability of the financial system while improving its efficiency.

Directors welcomed Japan's progress in structural reforms. They noted that the current strong expansion reflects in part the payoff from vigorous financial and corporate sector restructuring in the past. Looking ahead, Directors observed that steps to downsize the public sector, make labor and product markets more flexible, and liberalize trade could lift productivity further.

Directors stressed that accelerating structural reform would pay additional dividends to Japan and the world. The stronger underlying growth these reforms would engender would facilitate fiscal consolidation, while helping to support living standards in the face of rapid population aging. Directors noted that, as part of a package of policy measures involving a number of countries, reforms would also support a more balanced pattern of global growth and an orderly resolution of global current account imbalances. For all these reasons, they encouraged the authorities to maintain an ambitious reform program.

Directors expressed appreciation for Japan's generous official development assistance, as well as for its financial and other support for the Fund's technical assistance activities.

Public Information Notices (PINs) form part of the IMF's efforts to promote transparency of the IMF's views and analysis of economic developments and policies. With the consent of the country (or countries) concerned, PINs are issued after Executive Board discussions of Article IV consultations with member countries, of its surveillance of developments at the regional level, of post-program monitoring, and of ex post assessments of member countries with longer-term program engagements. PINs are also issued after Executive Board discussions of general policy matters, unless otherwise decided by the Executive Board in a particular case. The Staff Report for the 2006 Article IV Consultation with Japan is also available. 
Japan: Selected Economic Indicators

\begin{tabular}{|c|c|c|c|c|}
\hline & 2003 & 2004 & 2005 & $\begin{array}{l}\text { Proj. } \\
2006\end{array}$ \\
\hline Real GDP 1/ & 1.8 & 2.3 & 2.6 & 2.9 \\
\hline Private consumption & 0.6 & 1.9 & 2.1 & 2.1 \\
\hline Nonresidential investment & 6.2 & 4.7 & 7.8 & 7.3 \\
\hline Residential investment & -0.9 & 2.0 & -0.7 & 4.9 \\
\hline Public investment & -10.8 & -8.8 & -5.9 & -2.5 \\
\hline Public consumption & 2.3 & 2.0 & 1.7 & 0.9 \\
\hline Stockbuilding (contribution to growth) & 0.3 & -0.2 & 0.1 & 0.0 \\
\hline Foreign balance (contribution to growth) & 0.6 & 0.8 & 0.3 & 0.4 \\
\hline Exports of goods and services & 9.0 & 13.9 & 7.0 & 11.2 \\
\hline Imports of goods and services & 4.0 & 8.5 & 6.3 & 10.3 \\
\hline \multicolumn{5}{|l|}{ Inflation } \\
\hline GDP deflator & -1.6 & -1.2 & -1.3 & 0.0 \\
\hline $\mathrm{CPI}$ & -0.3 & 0.0 & -0.3 & 0.6 \\
\hline Unemployment rate (period average, percent) & 5.3 & 4.7 & 4.4 & 4.1 \\
\hline \multicolumn{5}{|l|}{ Current account balance } \\
\hline Billions of U.S. dollars & 136.2 & 172.1 & 165.7 & 169.6 \\
\hline Percent of GDP & 3.2 & 3.8 & 3.6 & 3.7 \\
\hline \multicolumn{5}{|c|}{ General government balances (percent of GDP, FY) } \\
\hline Balance including social security & -7.8 & -5.6 & -5.3 & -5.0 \\
\hline Balance excluding social security & -8.0 & -6.0 & -4.9 & -4.7 \\
\hline Structural balance 2/ & -6.9 & -4.7 & -5.0 & -5.0 \\
\hline \multicolumn{5}{|c|}{ Money and credit (12-month growth rate; end period) } \\
\hline Base money & 13.2 & 4.2 & 1.0 & $-16.23 /$ \\
\hline $\mathrm{M} 2+\mathrm{CDs}$ (period average) $4 /$ & 1.7 & 1.9 & 1.9 & $1.23 /$ \\
\hline Bank lending 4/ & -5.2 & -3.2 & -0.3 & $1.83 /$ \\
\hline \multicolumn{5}{|l|}{ Exchange and interest rates (period average) } \\
\hline Yen/dollar rate & 115.9 & 108.2 & 110.2 & $113.25 /$ \\
\hline Real effective exchange rate $6 /$ & 80.2 & 79.9 & 74.8 & $71.36 /$ \\
\hline 3-month CD rate & 0.09 & 0.06 & 0.06 & $0.285 /$ \\
\hline 10-year government bond yield & 1.00 & 1.51 & 1.39 & $1.875 /$ \\
\hline
\end{tabular}

Sources: Global Insight, Nomura database and IMF staff estimates and projections.

$1 /$ Annual growth rates and contributions are calculated from seasonally adjusted data. The official outturn based on annual data for GDP growth in 2004 was 2.7 percent.

2/ Including social security, excluding bank support.

3/ June 2006.

4/ From April 1998 onward, data reflect the inclusion of foreign banks, foreign trust banks and Shinkin banks in the monetary survey.

5/ July 26, 2006.

6/ Based on normalized unit labor costs; $2000=100$. Figure for 2006 is as of May. 